\title{
The 1.35-Ma-long terrestrial climate archive of Tenaghi Philippon, northeastern Greece: Evolution, exploration, and perspectives for future research
}

\author{
Jörg Pross ${ }^{1,2 *}$, Andreas Koutsodendris ${ }^{1}$, Kimon Christanis ${ }^{3}$, \\ Tobias Fischer ${ }^{1}$, William J. Fletcher ${ }^{4}$, Mark Hardiman ${ }^{5}$, Stavros Kalaitzidis ${ }^{3}$, \\ Maria Knipping $^{6}$, Ulrich Kotthoff ${ }^{7}$, Alice M. Milner ${ }^{8}$, Ulrich C. Müller \\ Gerhard Schmiedl ${ }^{7}$, George Siavalas ${ }^{3,10}$, Polychronis C. Tzedakis ${ }^{11}$, \\ and Sabine Wulf ${ }^{1,2,12}$
}

With 8 figures

\begin{abstract}
Since the first pollen analyses from core material in the 1960s, the limnotelmatic sequence of Tenaghi Philippon, located within the subsurface of the Drama Basin of NE Greece, has been recognized as an exceptional archive of terrestrial climate and ecosystem dynamics for the Quaternary in Europe. The polleniferous sequence covers the last $\sim 1.35 \mathrm{Ma}$ continuously, spanning at least 19 consecutive glacial-interglacial cycles. Analyses of Tenaghi Philippon as based on the drillcores from the 1960s were restricted to a millennial-scale resolution. Because the original cores have deteriorated, the archive's potential for analyzing abrupt (i.e., centennial- to decadal-scale) climate and ecosystem change has long remained unexplored. Therefore new drilling campaigns were carried out in 2005 and 2009 to recover the $0-60 \mathrm{~m}$ and 50-200 m depth intervals of the archive, respectively. The new cores (recovery: 97.8 and $99.0 \%$, respectively) allow characterization of the evolution of abrupt climate and ecosystem variability across the full range of climatic
\end{abstract}

\footnotetext{
Authors' addresses:

${ }^{1}$ Paleoenvironmental Dynamics Group, Institute of Earth Sciences, Heidelberg University, Im Neuenheimer Feld 234, D-69120 Heidelberg, Germany.

2 Biodiversity and Climate Research Center (BiK-F), Senckenberganlage 25, D-60325 Frankfurt, Germany.

3 Department of Geology, University of Patras, GR-26504 Rio-Patras, Greece.

${ }^{4}$ Quaternary Environments and Geoarchaeology, Geography, School of Environment and Development, University of Manchester, Manchester, M13 9PL, United Kingdom.

${ }^{5}$ Department of Geography, University of Portsmouth, Portsmouth, PO1 3HE, United Kingdom.

${ }^{6}$ Institute of Botany, University of Hohenheim, Garbenstraße 30, D-70599 Stuttgart, Germany.

${ }^{7}$ Center for Earth System Research and Sustainability, Institute of Geology, Hamburg University, Bundesstraße 55, D-20146 Hamburg, Germany.

${ }^{8}$ Department of Geography, Royal Holloway, University of London, Egham, Surrey, TW20 0EX, United Kingdom.

${ }^{9}$ Parlamentsstraße 32, D-60385 Frankfurt, Germany.

${ }^{10}$ Present address: Shell Global Solutions International B.V., Kessler Park 1, 2288 GS, Rijswijk, The Netherlands.

11 Department of Geography, University College London, London, WC1E 6BT, United Kingdom.

12 Helmholtz Centre Potsdam, GFZ German Research Centre for Geosciences, Section 5.2 - Climate Dynamics and Landscape Evolution, Telegrafenberg, D-14473 Potsdam, Germany.

* Corresponding author; E-Mail: joerg.pross@geow.uni-heidelberg.de
} 
boundary conditions realized during the late obliquity-dominated '41-ka world' and the eccentricity-dominated ' 100 -ka world'. The resulting climate data will also assist paleoanthropologists in resolving the dispersal dynamics of archaic and modern humans into Eurasia. In light of these new research initiatives, and because much of the previous literature on Tenaghi Philippon is from sources that are partially difficult to access, we here provide a review of the geological evolution of the Tenaghi Philippon archive, its present-day environmental conditions and its exploration history. We further give a synopsis of recent work based on the new cores and discuss the perspectives for future studies.

Key words. Eastern Mediterranean, abrupt climate change, terrestrial ecosystems, pollen, scientific drilling

\section{Introduction}

In light of the increasing anthropogenic influence on the Earth's climate system, understanding the mechanisms, magnitudes and regional differentiation of climate change is a prerequisite for extending the lead time for mitigation and adaptation (e.g., Piontek et al. 2014). This holds particularly true for climate change that occurs on short (i.e., decadal to centennial) time scales. During the late Quaternary, such abrupt change has repeatedly affected the Earth, with temperatures locally increasing by $\sim 10^{\circ} \mathrm{C}$ within human time scales (Severinghaus et al. 1998, Grachev and Severinghaus 2005). Available evidence suggests that abrupt climate change may also recur in the near future, with potentially severe consequences for ecosystems and human societies (National Research Council 2002, Alley et al. 2003).

Temporally highly resolved records of the pattern and timing of short-term climate change over the last $800 \mathrm{ka}$ as superimposed on long-term, Milankovitchband climate signals have been obtained primarily from ice cores from the high latitudes (e.g., Dansgaard et al. 1993, EPICA community members 2004, Barker et al. 2011). Considerably less information on the characteristics of short-term climate variability during that time, and notably the impact of this variability on terrestrial ecosystems, is available for the middle and lower latitudes. These latitudes harbor, however, the majority of the world's population; hence, they will witness the strongest socio-economic consequences of future climate change.

Located in an intermediate position between the climate systems of the higher (i.e., influenced by the westerlies and the Russian High) and lower (i.e., monsoonally influenced) latitudes, the Mediterranean region is highly susceptible to short-term climate change. For the past centuries, this climatic sensitivity is documented for a large number of different settings. During the Little Ice Age, the southern Balkans expe- rienced a marked increase in the frequency of cold spells in winter, which repeatedly caused crop failures and ultimately famines (Xoplaki et al. 2001). Marine instrumental data from the early 1990s show a displacement of deep-water production from the Adriatic to the Aegean Sea after a series of particularly cold winters in the Aegean region (Roether et al. 1996). In line with these observations, a marked temperature rise and a precipitation decrease across the Mediterranean region are predicted for the next decades (Intergovernmental Panel on Climate Change 2013, Lionello et al. 2014, and references therein).

For the late Quaternary, valuable insights into the short-term climate variability of the Mediterranean region have become available through high-resolution proxy records from the Aegean Sea and its borderlands. They document a strong sensitivity to shortterm climate change for both the marine (e.g., Rohling et al. 2002, Schmiedl et al. 2010, Kotthoff et al. 2011) and the terrestrial realm (e.g., Kotthoff et al. 2008a, Fleitmann et al. 2009, Pross et al. 2009, Müller et al. 2011). Notably, climate information from biotic proxies such as pollen is available for this region across the full range of climatic boundary conditions experienced during the Quaternary. The persistence of glacial tree refugia along the northern borderlands of the Aegean Sea allows for a minimum time lag between atmospheric forcing and vegetation response as it may result from taxon-specific migration times (Tzedakis 1993). This is in contrast to western and Central Europe where plant migration lags have notoriously hampered the understanding of abrupt climate change under boundary conditions other than those realized during full interglacials (Müller et al. 2003, Koutsodendris et al. 2012).

In view of the above, the terrestrial climate archive preserved in the Philippi peatland of the Drama Basin (Macedonia, NE Greece) plays a key role. This archive, widely termed "Tenaghi Philippon", has been appreciated as harbouring a unique record of terrestrial 
climate and ecosystem dynamics for the Quaternary in Europe since the initiation of pollen-based vegetation analyses in the late 1960s (Wijmstra 1969). The prominent role of the Tenaghi Philippon archive is due to (i) its stratigraphical length, which comprises the last $\sim 1.35 \mathrm{Ma}$ and at least 19 consecutive glacial-interglacial cycles (Tzedakis et al. 2006); (ii) its likely stratigraphical completeness as suggested by its climatostratigraphical similarity with deep-sea (Wijmstra and Groenhart 1983) and ice-core records (Fletcher et al. 2013); (iii) its exceptionally low liability to sediment redeposition, resulting from its peat-dominated lithology and the morphological characteristics of the Drama Basin, i.e., large size and low intra-basinal topographical gradients; (iv) its proximity to glacial refugia of thermophilous plants, which minimizes the time lag between climate forcing and vegetation response as documented in pollen data (Tzedakis 1993); and (v) its strategic position along a prominent hominid migration route, which allows to constrain the environmental conditions under which archaic and modern humans dispersed into Europe (Müller et al. 2011, Tourloukis and Karkanas 2012, Hublin 2014).

Climatostratigraphical analyses of the Tenaghi Philippon archive as accessible through the first generation of coring campaigns from the 1960s were restricted to a temporal resolution within the Milankovitch time band. Because the cores from these campaigns have deteriorated, its potential for deciphering the magnitude and tempo of abrupt climate change has long remained unexploited. Therefore, in 2005 a campaign was initiated to re-drill the upper $60 \mathrm{~m}$ of the archive; the highquality cores obtained allow the characterisation of short-term climate variability from the Holocene to Marine Isotope Stage (MIS) 9 c ( $312 \mathrm{ka} \mathrm{BP}$; Pross et al. 2007, Fletcher et al. 2013). Stimulated by this success, a second, larger-scale drilling campaign was carried out in 2009 in order to recover the remainder of the archive, allowing to extend the analysis of short-term climate variability into the early Pleistocene.

In light of these new research efforts, and because much of the previously available information on Tenaghi Philippon has been published separately in a number of different sources that are partially difficult to access, we here provide a review of the geological evolution of the Tenaghi Philippon archive, its presentday environmental setting and its exploration history. Moreover, we give a synopsis of the outcome of recent studies, provide selected new data, and discuss the perspectives for future research.

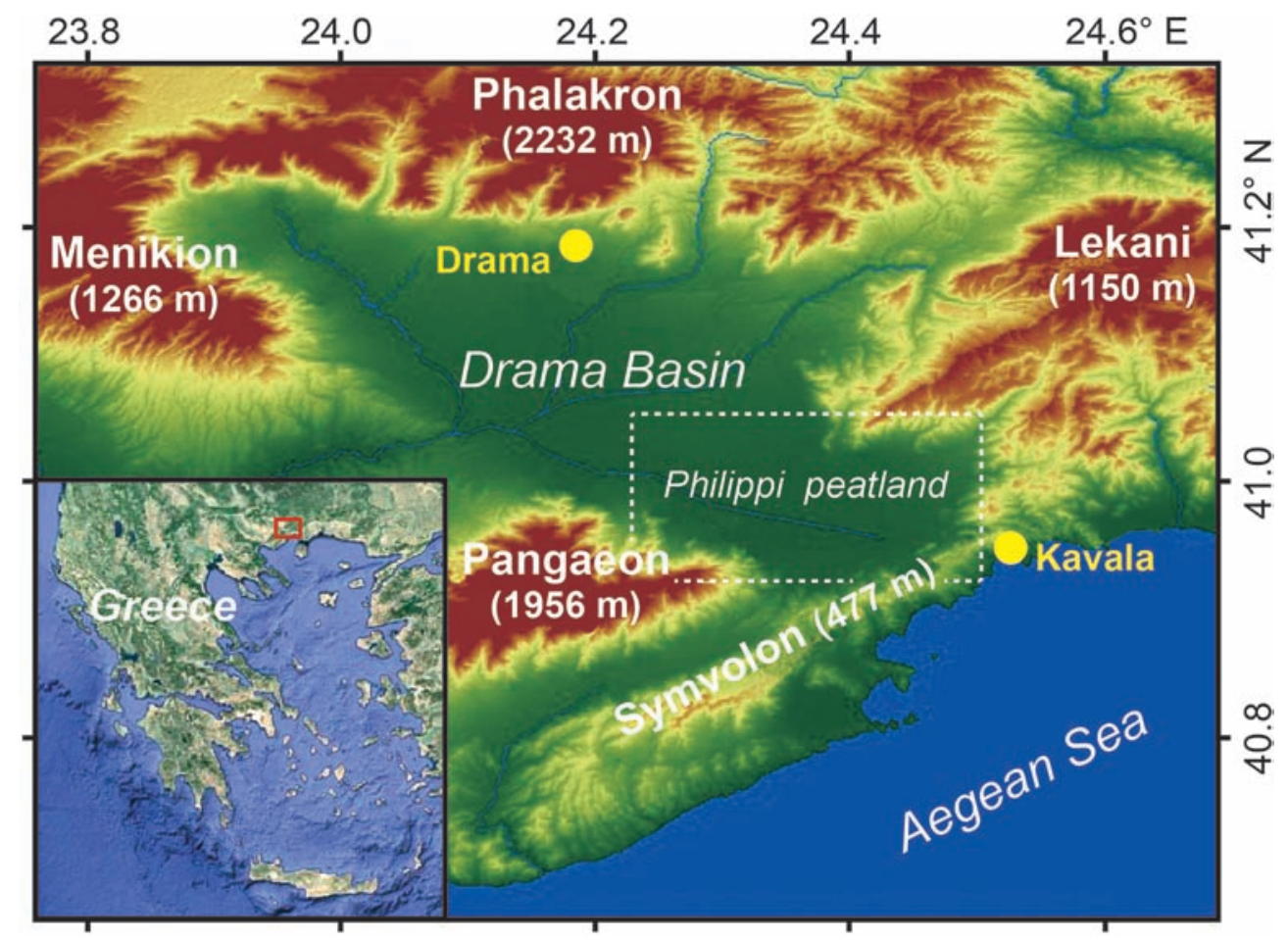

Fig. 1. Relief map of the Drama Basin and its vicinity in northeastern Greece. Dotted white rectangle marks position of the close-up map shown in Fig. 2. 


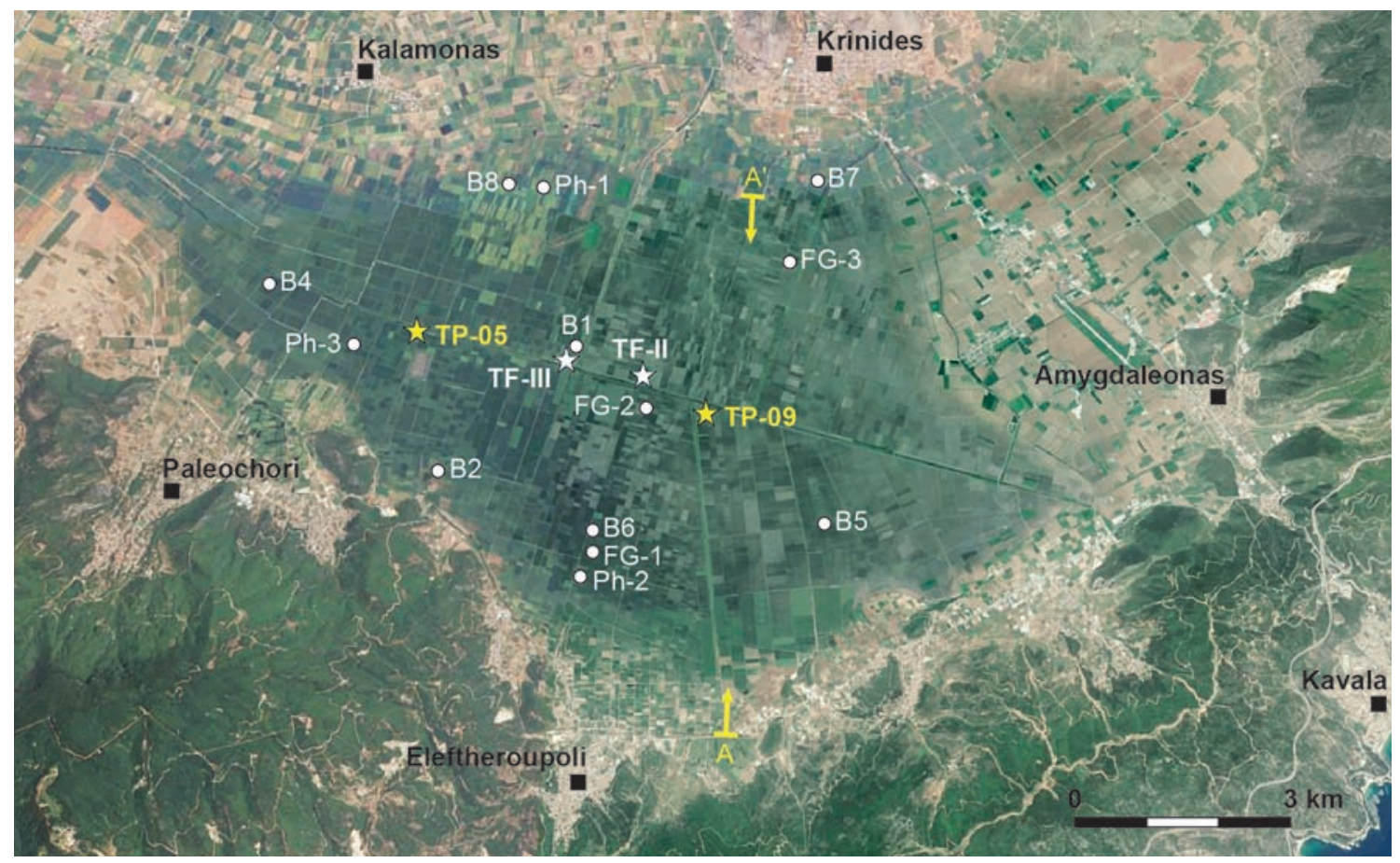

Fig. 2. Aerial view of the Philippi peatland with locations of drill sites. White dots mark positions of selected shallow (up to $12 \mathrm{~m}$ ) drillings of Christanis (1983) and Kalaitzidis (2007), white asterisks mark positions of deep drillings TF-II and TF-III of Wijmstra and co-workers. Yellow asterisks mark positions of TP-2005 and TP-2009 drill sites. Letters A and A' mark endpoints of transect shown in Fig. 3. See text for discussion.

\section{The Tenaghi Philippon site}

\subsection{Geological and topographical framework}

The Philippi peatland, which includes the Tenaghi Philippon drill sites and covers a surface area of $\sim 55 \mathrm{~km}^{2}$, is situated in the southeastern part of the intramontane Drama Basin of northeastern Greece (Figs. 1, 2). With an approximate size of $700 \mathrm{~km}^{2}$, the Drama Basin represents the largest of numerous low-elevation graben structures in northeastern Greece and the Balkanides that formed as a result of post-orogenic, arc-parallel extension starting in the late early or middle Miocene; the grabens are bound by normal faults and tend to become younger from east to west (compare Dumurdzanov et al. 2005, and Hoffmann et al. 2010). Reaching an elevation of $\sim 200 \mathrm{~m}$ a.s.l. in its northern part and $\sim 40 \mathrm{~m}$ in the south, the Drama Basin is bounded by mountain ranges to the north (Phalakron Range, up to 2,232 m high), west (Menikion Range 1,963 m), south (Pangaeon Range 1,956 m) and east (Lekanis Mountains, 1,150 m); in the southeast, the Symvolon Range (477 m) separates the basin from the Aegean Sea (Fig. 1).
Geologically, the basement and graben shoulders consist of Permian to Eocene metasediments (predominantly marbles; Del Moro et al. 1990, Kilias and Mountrakis 1990), and Cretaceous to Oligocene granites and granodiorites (Sklavounos 1981, Eleftheriadis and Lippolt 1984, Soldatos and Christofides 1986). Despite the existence of (unpublished) seismic survey and borehole log data, the Neogene succession of the Drama Basin is still poorly known; its overall thickness is estimated at $\sim 2,000 \mathrm{~m}$ (Kaouras et al. 1991). During the Miocene and particularly the Pliocene, fluvial, lacustrine and terrestrial strata were deposited; today, they outcrop along the western border of the basin (Bornovas and Rondogianni-Tsiambaou 1983). Marine ingressions, as they extended into the adjacent Strymon Basin to the west during the Tortonian, late Messinian and Calabrian, did not reach the Drama Basin (Gramann and Kockel 1969). From the early Pleistocene onwards, limnic and telmatic conditions prevailed across much of the basin, at times covering an area of $\sim 150 \mathrm{~km}^{2}$ (Christanis et al. 1998). They resulted in a thick sequence of marls, calcareous clays, and notably lignite and fen peat (compare Fig.3). Along the basin margins, these autochthonous sedi- 
ments interfinger with coarse-grained alluvial fans derived from the surrounding slopes. During periods of enhanced tectonic activity, the alluvial fans advanced transiently towards the basin center, thereby causing repeated disruptions of the telmatic depositional setting. These advances are documented as clastic interbeds separating the subsurface lignite seams in the central part of the Drama Basin (Kaouras et al. 1991, Filippidis et al. 1996).

Owing to a southeastward shift of the basin depocenter, telmatic conditions ceased in the central Drama Basin after the Last Interglacial (Eemian), whereas in the Philippi peatland they continued into the Holocene and were only terminated through largescale drainage efforts from the 1930s onwards. As revealed through drillings in the 1960s and 1970s performed by the Greek Institute of Geology and Mineral Exploration (IGME) and the Public Power Corporation of Greece (PPC) (Melidonis 1981), these processes yielded a sedimentary sequence that consists nearexclusively of fen peat and reaches a thickness of nearly $200 \mathrm{~m}$. This makes the Philippi peatland the thickest known peat-dominated succession in the world (Christanis et al. 1998). The peat has an estimated dry weight of nearly $1 \mathrm{Gt}$ (Melidonis 1981); its rank increases with depth to the 'soft brown coal' stage (Teichmüller 1968). Based on analyses of Holocene and Lateglacial material, the peat originates mainly from Cyperaceae, namely Carex spp. and Cladium mariscus. Its ash yield ranges from 11.4 to $53.4 \%$ (Christanis 1983), and its geochemical and organic petrographical composition shows distinct differences between the Lateglacial and the Holocene owing to changes in hydrology and source areas (Christanis 1983, Kalaitzidis and Christanis 2004, Kalaitzidis et al. 2006, Kalaitzidis 2007). The lower part of the peat sequence in the Philippi peatland is likely correlative to the lignite sequence known from the subsurface of the central Drama Basin (Kaouras et al. 1991).

In the 1980s, numerous reconnaissance wells were drilled in the Drama Basin by IGME and PPC in order to constrain the extent of the Philippi peat deposit; this led to the discovery of the Drama Basin lignite deposits (Broussoulis et al. 1991, Kaouras et al. 1991). The mineable lignite reserves are estimated at $0.96 \mathrm{Gt}$, making the Drama Basin the second largest lignite deposit in Greece (Koukouzas et al. 1997). However, the deposit has yet remained unexploited, and further exploration rights expired in 2005. Because the competitiveness of lignite-fired electricity generation has decreased over the recent past, future exploitation appears currently unlikely (Commission of the European Communities 2008).

At present, the Drama Basin is drained by several streams that discharge into the Angitis River, which itself forms a tributary of the Strymon River flowing from western Bulgaria into the North Aegean Sea. The southern Drama Basin, including the Philippi peatland, is additionally drained by channels and ditches that were built in the 1930s and 1940s in order to fa-

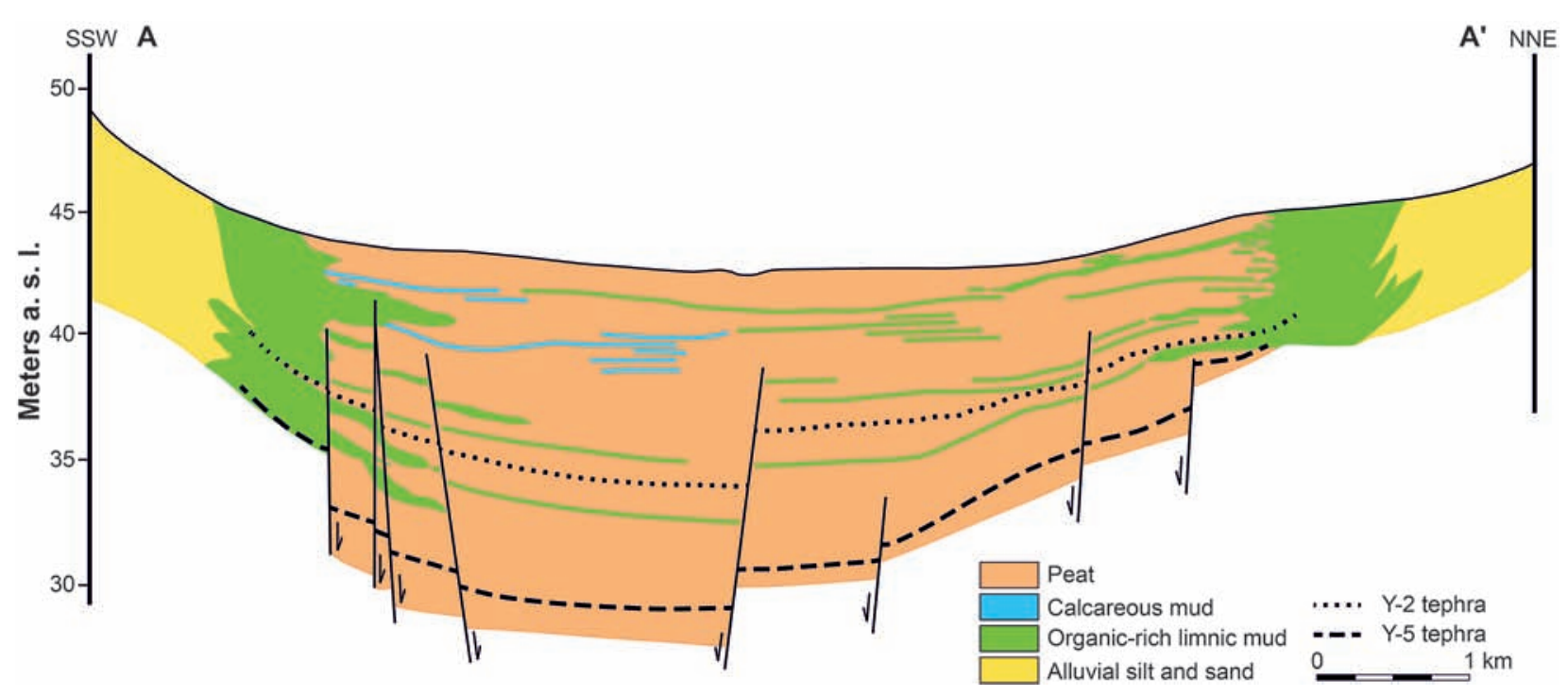

Fig. 3. Geological transect across the Philippi peatland, showing subsurface lithology to a depth of $\sim 20 \mathrm{~m}$. See Fig. 2 for location of transect. Modified after Christanis (1983). 
cilitate an agricultural use of the area; they also flow into the Angitis River (Georgakopoulos et al. 2001). A shallow unconfined aquifer is situated $\sim 1-1.5 \mathrm{~m}$ below the surface in the central part of the basin, whereas there is a karstic aquifer on the basin margins. The two aquifers are unconnected (Georgakopoulos et al. 2001).

\subsection{Climate}

Located close to the northeastern limits of the Mediterranean climate region, eastern Macedonia (and thus also the Drama Basin) is exposed to a characteristic Mediterranean seasonal regime modified by continental influence. Winters are generally colder (with the frequent occurrence of frost) than under a Mediterranean climate sensu stricto; notably, they are punctuated by anomalously cold and windy episodes connected to southward outbreaks of polar air masses from the Russian High (Saaroni et al. 1996). Moisture availability, which is mainly linked to the penetration of westerly storm tracks across southern Europe and Mediterranean cyclogenesis, exhibits a strong seasonal pattern, with most precipitation occurring during the cold season; however, summers are generally wetter than under Mediterranean climates, thereby being reminiscent of Central European conditions (Xoplaki et al. 2003, Lionello et al. 2006, and references therein).

Based on the period 1975-2004, the mean annual temperature in the southeastern Drama Basin is $14.4^{\circ} \mathrm{C}$; mean July and January temperatures are 25.4 and $5.4^{\circ} \mathrm{C}$, respectively. The mean annual precipitation amounts to $459 \mathrm{~mm}$, with September being the driest (mean: $18 \mathrm{~mm}$ ) and December (mean: $55 \mathrm{~mm}$ ) the wettest months (www.geoclima.eu).

The Drama Basin and its surroundings exhibit a strong mesoclimatic differentiation owing to the region's pronounced topography and close proximity to the Aegean Sea. In particular, winters are much colder on the basin floor than at comparable elevations along the nearby coast. This effect is mainly due to the katabatic flow of cold air masses from the surrounding mountains into the basin plain; it is further enhanced by the intense nocturnal radiation and snow cover on the ground (Flocas and Angouridakis 1979). As a consequence, the Drama Basin ranks among the localities with the lowest minimum temperatures for Greece (Flocas and Angouridakis 1979). Comparable scenarios occur widely in intramontane basins of eastern Macedonia. One of the best known examples comes from the town of Kato Nevrokopi, which is located within an intermontane plain $\sim 15 \mathrm{~km}$ NNW of the Drama Basin at an elevation of $\sim 500 \mathrm{~m}$. As a result of the topography-induced mesoclimatic effects described above, Kato Nevrokopi has yielded the lowest temperature $\left(-28^{\circ} \mathrm{C}\right)$ ever reported in Greece; in the winter of 2008/09, mean daily temperatures remained below freezing over 70 out of 90 days, and they did not rise above $-10.6^{\circ} \mathrm{C}$ for several days (Dotsika et al. 2010).

\subsection{Present-day vegetation}

Considering the significance of Tenaghi Philippon for pollen-based climate and ecosystem reconstructions, the composition of the vegetation surrounding the Drama Basin merits special attention. The original vegetation of the basin and its surroundings has been altered strongly by human activities. Specifically, the vegetation on the mountain slopes surrounding the basin has been affected by the region's long tradition of cattle grazing (Karagiannakidou and Kokkini 1988), and the once extensive Philippi fen has undergone a near-complete transformation into arable land since the 1930s (Wijmstra 1969, Christanis 1983). Today, this land is used almost exclusively for corn production.

The formerly abundant aquatic environments in the Philippi fen prior to land-reclamation efforts were home to water plants such as Nymphaea alba and Polygonum amphibium. Within the telmatic zone that prevailed along the basin margins, herbaceous elements included Iris pseudacorus, Phragmites communis and Typha angustifolia; wetland trees comprised Alnus sp., Betula pendula, Populus sp., and Salix sp. (Lavrentiadis 1956, Wijmstra 1969).

Depending on orientation and elevation, the slopes of the mountain ranges surrounding the basin are today covered by woodlands and scrublands; up to an altitude of $\sim 250 \mathrm{~m}$ a.s.1., these are mainly formed by Arbutus unedo, Calycotome villosa, Cistus salviifolius, C.monspeliensis, Erica arborea, Juniperus sp., Paliurus aculeata, Pistacia terebinthus, and Quercus ilex (Wijmstra 1969). Above $\sim 300 \mathrm{~m}$, a scrub zone with Carpinus orientalis and evergreen Quercus (Q.coccifera and Q.ilex) is present, while the first trees of C.orientalis and evergreen Quercus (Q.coccifera) along with Castanea sativa, Lonicera etrusca, and Vitis silvestris appear at $\sim 450 \mathrm{~m}$. Acer sp., Cornus mas, Corylus avellana, Crataegus monogyna, Ostrya carpinifolia, Pinus nigra, deciduous Quercus (e.g., Q.frainetto, Q.pubescens, Q.petraea), and Tilia tomentosa are the dominant trees and shrubs at higher 
altitudes, with P.nigra occurring from $\sim 600 \mathrm{~m}$ to $\sim 1,600 \mathrm{~m}$; Abies alba and A.borissii-regis are also present (Wijmstra 1969, Karagiannakidou and Kokkini 1987, Dafis et al. 1997). Fagus appears from $\sim 450 \mathrm{~m}$ upwards and reaches altitudes of up to 1,600 m, with Fagus-dominated forests being mainly confined to east-facing slopes (Karagiannakidou and Kokkini 1987, Karagiannakidou et al. 1995, Tsiripidis and Athanasiadis 2003). It is noteworthy that Betula pendula and Picea abies occur in the Pangaeon and Rodopi Ranges, respectively, which represents the southernmost occurrences of these taxa in the Balkans (Dafis et al. 1997). Sub-alpine and alpine meadows, which harbour abundant local and regional endemics (Dafis et al. 1997), extend mainly above $\sim 1,600 \mathrm{~m}$ (Quézel 1968, Karagiannakidou and Kokkini 1987, Karagiannakidou et al. 1995).

\section{Exploration efforts in the 1960 s to 1990 s}

With the aim of characterizing the lateral extent, vertical thickness and depth distribution of subsurface peat and lignite, the first drilling operations in the Drama Basin were economically rather than scientifically motivated. These reconnaissance wells, which also made possible an initial palynological study (van der Hammen et al. 1965), reached a depth of $\sim 390 \mathrm{~m}$ (Christanis et al. 1998). They yielded important information on the architecture and sedimentary succession of the basin that, together with the results of unpublished seismic surveys, paved the way for the scientifically motivated coring campaigns carried out in the Philippi peatland during the 1960s and 1970s.

The first of these scientific drilling campaigns, conducted in 1963, yielded the 120-m-long core TF-II from the center of the Philippi peatland (Wijmstra and Groenhart 1983; Fig. 2). The core consists mainly of peat; it was subsequently analyzed palynologically at a resolution of $20 \mathrm{~cm}$ by Wijmstra $(1969 ; 0-30 \mathrm{~m})$, Wijmstra and Smit (1976; 30-78 m), and Van der Wiel and Wijmstra (1987a; 78-120 m).

In 1976 (Van der Wiel and Wijmstra 1987b) or 1977 (Wijmstra and Groenhart 1983), a second core (TF-III) was recovered $\sim 1 \mathrm{~km}$ west of the TF-II drillsite (Fig.2). It penetrated a palynologically productive succession of peat and clay to a depth of $197.8 \mathrm{~m}$; further downhole and to the final depth of $280 \mathrm{~m}$, palynologically barren clays and sands were encountered. Palynological samples were taken at least every $30 \mathrm{~cm}$, except for intervals where core loss precluded such a resolution (Mommersteeg et al. 1995); the results were published for the core interval from 112.8 to $197.8 \mathrm{~m}$ by Van der Wiel and Wijmstra (1987b).

Although these analyses were carried out at relatively low temporal resolution (mean: $\sim 1.7 \mathrm{ka}$ ), the obtained tree-pollen curve was recognized to show a close correlation to the benthic $\delta^{18} \mathrm{O}$ record of deepsea core V28-239 from the East Pacific (Wijmstra and Groenhart 1983, Van der Wiel and Wijmstra 1987b, Wijmstra and Young 1992). Aided by the detection of the Jaramillo subchron between 195 and $210 \mathrm{~m}$ in core TF-III (Van der Wiel and Wijmstra 1987b), this correlation yielded a first, tentative assignment of MIS numbers to the Tenaghi Philippon pollen record. The spliced pollen record from cores TF-II and TF-III was estimated to span the past $\sim 900 \mathrm{ka}$ (Van der Wiel and Wijmstra 1987b) respectively $\sim 975 \mathrm{ka}$ (Mommersteeg et al. 1995), an age that was later corrected to $\sim 1.35 \mathrm{Ma}$ (Tzedakis et al. 2006).

Insights into the vegetation dynamics during interglacial-glacial cycles as derived from the TF-II and TF-III cores were presented by Wijmstra et al. (1990), and Wijmstra and Young (1992). They identified typical interglacials at Tenaghi Philippon to start with relatively warm, humid conditions favouring the growth of open woodlands characterized by the occurrence of Pistacia. This phase was followed by a transition to evergreen oak forests that themselves were replaced by summergreen open forests. Towards the end of interglacials, arboreal elements decreased, giving way to a steppe vegetation with Artemisia and Chenopodiaceae as it prevailed during glacials. Ecological interpretations based on the partially high percentages of Chenopodiaceae and other Amaranthaceae in the core were presented by Smit and Wijmstra (1970).

Its exceptional length and apparent stratigraphic completeness led to the recognition of Tenaghi Philippon as one of the most prominent terrestrial paleoclimate archives in Europe, and the pollen counts of Wijmstra and co-workers provided the palynological dataset for a large number of subsequent paleoclimatically and paleoceanographically oriented studies (e.g., Mommersteeg et al. 1995, Martrat et al. 2004, 2007, Tzedakis 2007, Müller and Pross 2007, Leroy et al. 2011).

While the millenial-scale resolution reached by Wijmstra and co-workers may at least to some extent reflect the scientific focus prevailing at that time, it can also be attributed to limitations in core recovery that for parts of the material precluded higher-resolution 
work. The cores from the TF-II and TF-III campaigns have long decomposed owing to their high organic matter content and are no longer available for analyses (H. Hooghiemstra 2014, pers. comm.). As a consequence, the potential of Tenaghi Philippon for analysing short-term variability in vegetation and climate dynamics has long remained untapped.

Independent of the deep drillings described above, a considerable number of shallow (up to $\sim 12 \mathrm{~m}$ long) cores spanning the Holocene and Lateglacial part of the Tenaghi Philippon sequence have been recovered using handheld coring devices (Greig and Turner 1974, Turner and Greig 1975, Christanis 1983, Christanis et al. 1998, Kalaitzidis and Christanis 2002, Kalaitzidis 2007). The coring sites are widely distributed over the Philippi peatland (Fig. 2), which allowed reconstruction of the depositional conditions during the Late Glacial and Holocene, and development of a spatially differentiated view of the shallow subsurface lithology.

The cores documented that the sediment is well suited for the preservation of tephra layers, thereby indicating the potential of the Tenaghi Philippon archive for tephrostratigraphical and tephrochronological research. Early work by Christanis (1983) revealed the presence of four macroscopically visible tephra layers; two of them were attributed to the widely known Y2 (Cape Riva eruption of Santorini, Aegean Arc; $22 \mathrm{ka}$ BP according to Wulf et al. 2002) and Y5 (Campanian Ignimbrite, Italy; 39 ka BP according to Pyle et al. 2006) tephras.

The other two layers, with depositional ages of $\sim 19 \mathrm{ka} \mathrm{BP}$ and 3.6-4.0 ka BP, were tentatively correlated with unknown eruptions from Santorini and Campi Flegrei, respectively (Christanis 1983). The original interpretation of Christanis (1983) was disputed by St. Seymour et al. (2004), who generated the first glass chemical data and interpreted the older unknown tephra layer $(\sim 19 \mathrm{ka} \mathrm{BP})$ to represent the Y2 tephra. This conundrum was later resolved through analysis of the TP-2005 core (compare Section 4.1). Nevertheless, already these early findings documented that due to its geographical position Tenaghi Philippon can provide an integrated record of eruptions both from the Italian and the Aegean volcanic provinces; this is in contrast to other long terrestrial archives from the western Balkans such as Lake Ohrid (Sulpizio et al. 2010) and Lake Prespa (Sulpizio et al. 2010, Damaschke et al. 2013) where tephras from the Aegean Arc have remained undetected.

\section{Tenaghi Philippon revisited: The 2005 and 2009 coring campaigns}

\subsection{The 2005 coring campaign}

In light of the scientific need to understand better the mechanisms and consequences of short-term climate change as outlined above, a campaign was initiated in the early 2000s to recover a new deep core from Tenaghi Philippon. With a focus on maximizing core recovery, this campaign aimed at retrieving the upper $60 \mathrm{~m}$ of the archive (Pross et al. 2007). Drilling took place over three weeks in April $20053.4 \mathrm{~km}$ west of the TF-II locality of Wijmstra and co-workers (coordinates: $40^{\circ} 58.40^{\prime} \mathrm{N}, 24^{\circ} 13.42^{\prime} \mathrm{E} ; 40 \mathrm{~m}$ a.s.l.; see Fig. 2 for site location). As previous reconnaissance efforts had shown that the peat was too soft to be recovered through wireline coring, the drilling contractor STÖLBEN (Zell an der Mosel, Germany) used a nonrotating probe driven by a pneumatic hammer system ("Düsterloh hammer") on a WIRTH Ecol drill rig. After recovery, the material was split into work and archive halves, lithologically described, photogrammetrically scanned, and sampled. It is now stored at $-15^{\circ} \mathrm{C}$ at the Institute of Earth Sciences, University of Heidelberg, and partially also at the Department of Geology, University of Patras.

The retrieved core TP-2005 covers the interval from the Holocene to MIS 9c; its bottom has an age of $\sim 312 \mathrm{ka}$ BP (Fletcher et al. 2013). The high core recovery (mean: $97.8 \%$ ) allowed the first decadal- to centennial-scale palynological analyses at Tenaghi Philippon, with a five- to tenfold increase in resolution from earlier work. The palynological preparation protocol comprised sediment freeze-drying, weighing, spiking with Lycopodium spores, treatment with $\mathrm{HCl}$ (10\%), $\mathrm{NaOH}(10 \%)$, HF (when necessary; 40\%), heavy-liquid separation with $\mathrm{Na}_{2} \mathrm{WO}_{4} \times 2 \mathrm{H}_{2} \mathrm{O}$ (when necessary), acetolysis, sieving through a $7 \mu \mathrm{m}$ mesh, and slide preparation using glycerine jelly.

To date, the newly generated pollen data comprise the Holocene (Pross et al. 2009, Peyron et al. 2011), MIS 2-4 (Müller et al. 2011), MIS 5 (Milner et al. 2012, 2013), and MIS 7e-9c (Fletcher et al. 2013). They have revealed an extreme sensitivity of the Tenaghi Philippon archive in recording abrupt climate change, including both warming events during glacial (Müller et al. 2011, Fletcher et al. 2013) and cooling events during interglacial boundary conditions (Pross et al. 2009, Milner et al. 2013). The pollen data show 
a close correspondence with Greenland ice-core records throughout the last $73 \mathrm{ka}$ (Pross et al. 2009, Müller et al. 2011), indicating a close coupling between the North Atlantic climate system and the NE Mediterranean region. This highlights the potential of a long, highly resolved pollen record from Tenaghi Philippon to serve as a proxy-based template for short-term climate variability in the northern hemisphere beyond the range of Greenland ice cores, which do not yield reliable climate information pre-dating the Last Interglacial because of ice disturbation and folding (NEEM community members 2013). From a more regional perspective, data from the new cores allow the identification of short-term environmental perturbations in the northern borderlands of the Aegean Sea as they may occur during times of marine sapropel formation (compare Konijnendijk et al. 2014, and Rohling et al. 2015). This is due to the close proximity of Tenaghi Philippon to the Aegean Sea and thus to a pivotal source of Mediterranean deep-water formation (Wu et al. 2000, Zervakis et al. 2000).

\subsubsection{Early Holocene}

For the early Holocene, Pross et al. (2009) analyzed the climatic impact of the $8.2 \mathrm{ka}$ BP climatic event on the vegetation surrounding Tenaghi Philippon. In the pollen data, which show a close structural correspondence with the $\delta^{18} \mathrm{O}$ signal in Greenland ice cores, the event is expressed in a marked deforestation, mainly at the expense of temperate and thermophilous trees (Fig.4). This vegetation turnover had originally been interpreted to represent the Younger Dryas due to its pronounced expression (Wijmstra 1969), a view that was supported by the radiocarbon dates available at that time. Later radiocarbon dating series of plant remains, bulk peat and pollen extracts, and tuning to the pollen record from marine core SL 152 (NE Aegean Sea; Kotthoff et al. 2008b), revealed a strong, material-dependent hard-water effect at Tenaghi Philippon for the early Holocene of up to $\sim 1.2 \mathrm{ka}$ (Pross et al. 2009). The ages derived from the radiocarbon dating series and the tuning to the SL 152 record converge at $\sim 11.0 \mathrm{ka} \mathrm{BP}$ (Pross et al. 2009), and the radiocarbon dates for pre-Holocene core intervals are consistent with the ages of detected tephra layers (Müller et al. 2011, Albert et al. 2015). This suggests a linkage of the hard-water effect to the prevailing hydrological regime. The pollen data from the TP-2005 core as available for MIS 1-3 suggest the highest humidity for the early Holocene (Müller et al. 2011), which is consistent with the observation that carbonate precipita- tion in the Philippi peatland was enhanced during that time due to the activity of karst springs contributing dissolved inorganic carbon from the Pangaeon Range (Christanis 1983, Kalaitzidis and Christanis 2002, Kalaitzidis 2007). Hence, the magnitude of the hardwater effect at Tenaghi Philippon is climatically driven; interglacial conditions (with higher humidity) caused a strong hard-water effect via the carbon input of active karst aquifers, whereas glacial climates (with drier conditions) lead to a strong reduction of the hardwater effect due to the reduced supply of these aquifers.

Pollen-based climate reconstructions yield an enhanced temperature seasonality for the $8.2 \mathrm{ka} \mathrm{BP}$ climatic event at Tenaghi Philippon, with $>4{ }^{\circ} \mathrm{C}$ cooler winters and $\sim 2{ }^{\circ} \mathrm{C}$ cooler summers; annual precipitation declined by $\sim 30 \%$, with a decrease in winter precipitation and an increase in summer precipitation leading to a reduced seasonal hydrological contrast (Pross et al. 2009, Peyron et al. 2011). Because the cooling (particularly in winter) strongly exceeds the values yielded by model simulations and proxy data representing coastal settings of the Aegean Sea, Pross et al. (2009) invoked particular mesoclimatic conditions for the Tenaghi Philippon site in order to reconcile this discrepancy. Their explanation relies on the katabatic flow of cold air from the surrounding mountains into the basin, combined with an increased influence of cold spells originating from the Russian High. Topography-induced mesoclimatic effects resulting from the katabatic flow of cold air masses characterize the present-day climate in numerous intermontane depressions of NE Greece, including the Drama Basin (Flocas and Angouridakis 1979, Dotsika et al. 2010). Hence, the observations connected to the $8.2 \mathrm{ka} \mathrm{BP}$ event allow to link mesoclimatic processes as they are operating in the Drama Basin today to those at work during the early Holocene. An impact of the $8.2 \mathrm{ka} \mathrm{BP}$ climatic event on vegetation has recently also been described by Panagiotopoulos et al. (2013) for the Lake Prespa basin, $270 \mathrm{~km}$ to the west of the Drama Basin.

\subsubsection{Last Glacial}

A major contribution from the study of long pollen sequences from southern Europe over the past four decades has been the documentation of interstadials during the last Pleniglacial (MIS 4-2) (e.g., Wijmstra 1969, Florschütz et al. 1971, Follieri et al. 1988, Brauer et al. 2007). In hindsight, the subsequent debate regarding the number and climatic significance of these episodes, which are characterized by weak forest ex- 
pansions (e.g., Pons and Reille 1988, Pons et al. 1992), highlights the critical importance of data with high temporal resolution. Exhibiting approximately millennial-scale resolution, the pioneering studies cited above typically reported five to seven palynologically-defined interstadial episodes, without coherent patterns of timing or amplitude between sites. However, the debat- ed relationship between southern European palynological interstadials and high-latitude warming events can, to a great extent, be resolved through intensification of analytical effort, at least at ecologically sensitive sites with robust independent chronologies. In this manner, the highly resolved pollen data spanning MIS 4-2 as generated from the TP-2005 core (Müller et al. 2011)

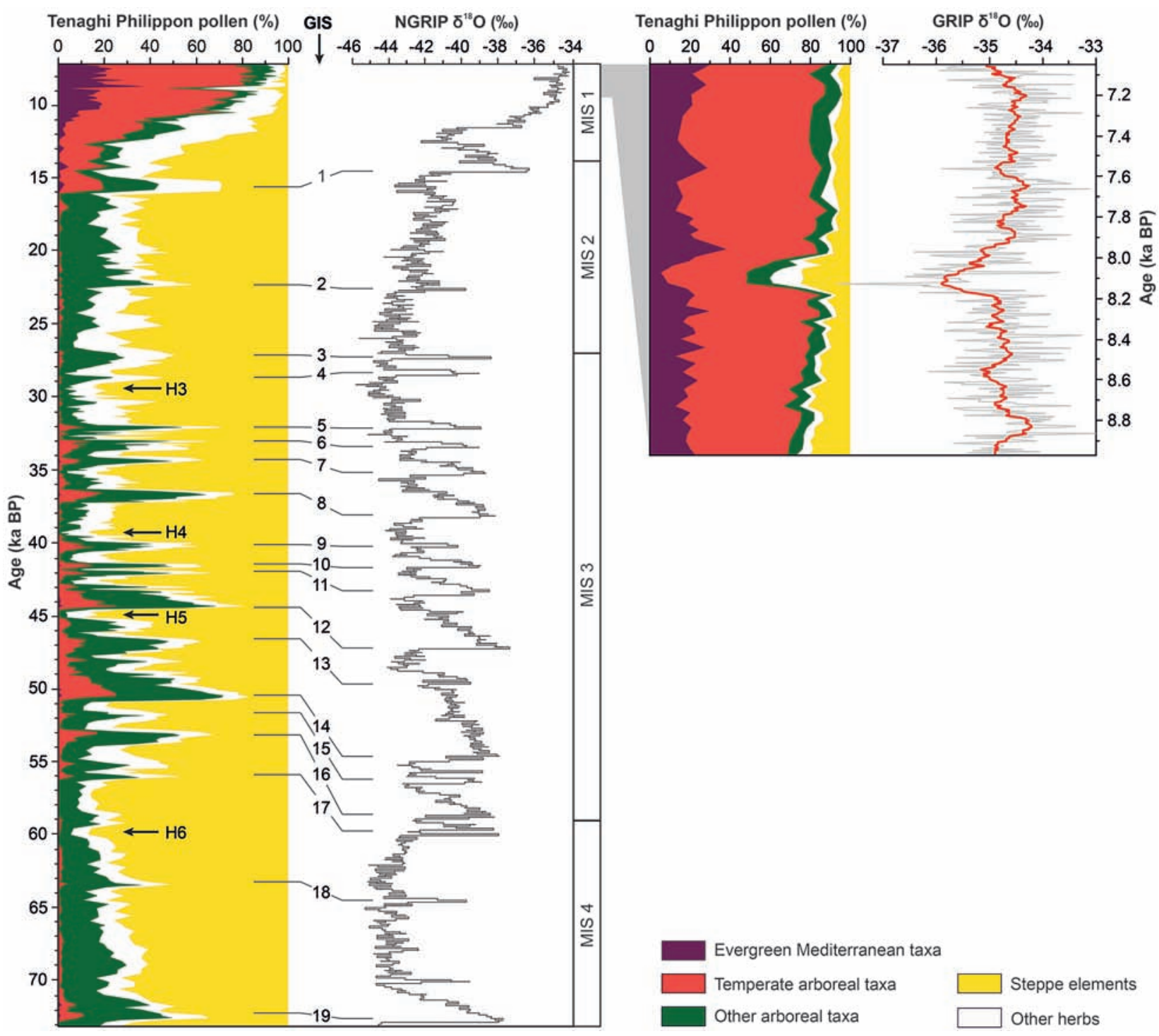

Fig. 4. Short-term climate variability under glacial and interglacial boundary conditions as documented in the high-resolution pollen record from Tenaghi Philippon core TP-2005. The shown interval comprises the Last Glacial and early Holocene interval ( 73-7 ka BP). Note the pronounced expression of Greenland interstadials (GIS) and Heinrich events (H) during the last glacial (left panel) and the $8.2 \mathrm{ka} \mathrm{BP}$ event during the early Holocene (right panel). Greenland $\delta^{18} \mathrm{O}$ ice-core records (GRIP: Dansgaard et al. 1993; NGRIP: NGRIP members, 2004) are shown for comparison, illustrating a close climatic coupling between the NE Mediterranean region and the North Atlantic realm. Evergreen Mediterranean taxa include Olea, Phillyrea, Pistacia, and Quercus ilex; temperate arboreal taxa include Acer, Buxus, Carpinus, Cornus, Corylus, Fagus, Fraxinus, Hedera, Ilex, Myrica, Quercus cerris, Q.robur, Rhamnus, Tilia, and Ulmus; other arboreal taxa include Abies, Alnus, Betula, Ephedra, Juniperus, Picea, Pinus, and Salix; steppe elements comprise Artemisia and Chenopodiaceae. Compiled after Pross et al. (2009) and Müller et al. (2011). 
provide unambiguous indications of event-for-event linkage between environmental change in the Mediterranean region and high-latitude climate variability, thereby extending the evidence for a close coupling of short-term climate change to the North Atlantic climate system beyond the Holocene. They show that interstadials characterized by short-term expansions of tree populations interrupted the general dominance of dry steppe biomes (Fig. 4). The age model, which is mainly based on radiocarbon dates and further augmented by imported ages of tephra layers, allows the correlation of all interstadials at Tenaghi Philippon with Greenland interstadials and vice versa. While all Greenland interstadials were linked with increases in tree populations facilitated by precipitation increases at Tenaghi Philippon, Greenland stadials were linked with dry steppe to desert-steppe biomes (Fig.4).

From a paleoanthropological perspective, these findings, in concert with the proximity of Tenaghi Philippon to the gateway for the immigration of anatomically modern humans (AMH) into Europe, are instrumental in constraining the climate conditions and timing of this process. Based on previously available archeological and genetic evidence, Müller et al. (2011) suggested that the ultimately successful spread of AMH from Asia Minor into Europe occurred during Greenland interstadial $12(\sim 47 \mathrm{ka} \mathrm{BP})$ when the onset of climatically favourable conditions rapidly converted the desert-steppe environment in the northern Aegean region into an open woodland. Because the climatic impact of preceding Heinrich event $\mathrm{H} 5$ on the northern Aegean region was as severe as that of the glacial maximum of MIS 4, Müller et al. (2011) further postulated a decisive role of this cooling event in the demise of Neanderthals and the dispersal of AMH across Europe. Recently, unexpectedly early evidence for the presence of AMH in Italy (Benazzi et al. 2011) and Great Britain (Higham et al. 2011), and for expansions of technocomplexes in western Eurasia (Hublin 2014) has become available. It has posed new questions regarding the timing of the earliest spread of AMH within Europe, the degree this spread was climatically or demographically driven, and the processes involved in the replacement of Neanderthal populations. These questions notwithstanding, its stratigraphic completeness, high temporal resolution, and strategic position with regard to the corridor of AMH immigration into Europe should allow the Last Glacial record from Tenaghi Philippon to serve as a climatic and environmental anchor point for future research on the colonisation of Europe by AMH. This is particular- ly the case where co-located tephra horizons can be identified, allowing direct synchronization between archeological records and the Tenaghi Philippon paleoarchive (e.g., Lowe et al. 2012).

\subsubsection{Last Interglacial and antepenultimate glacial}

For the Last Interglacial, approximately concurrent with MIS 5e, the new pollen data from core TP-2005 indicate a marked intra-interglacial climate variability that was most pronounced towards the end of the interglacial (Milner et al. 2012). Centennial-scale changes in forest cover and composition occurred on multiple occasions, documented by repeated expansions of cool mixed forest and/or steppe elements at the expense of temperate tree populations. Notably, the fluctuations in temperate tree pollen percentages exhibit a $\sim 1500$ a cyclicity during the declining stage of the interglacial, reminiscent of the $\sim 1500$ a cycles previously detected for the Holocene, the Last Glacial and the Last Interglacial (Bond et al. 1997, 2001, Müller et al. 2005). As the origin of these cycles is probably linked to circulation changes in the North Atlantic (Debret et al. 2007), their documentation at Tenaghi Philippon provides further evidence for a close coupling to the North Atlantic climate system.

While virtually all findings based on the TP-2005 core as portrayed above derive from pollen data, Milner et al. (2012) demonstrated the potential of the core material for integrated studies using different, independent climate proxies. Combining mineralogical, macrofossil and pollen data, they inferred an enhancement in the seasonality of precipitation for the early part of the Last Interglacial (130-119 ka BP); notably, the time window studied also comprises the interval of sapropel S5 deposition (129.5-121.4 ka BP; Ziegler et al. 2010) in the eastern Mediterranean Sea. By considering the seasonal aspect of proxy sensitivity, Milner et al. (2012) reconciled the seemingly contradictory pollen- and speleothem-based information with respect to the hydrological regime. With regard to sapropel formation, their data provide information on coeval terrestrial climate dynamics. For the interval corresponding to sapropel S5, they infer an enhanced winter precipitation in the northern borderlands of the Aegean Sea. This finding is in line with information on the early Holocene sapropel S1, for which a $~ 50 \%$ increase in winter precipitation in the northern borderlands of the Aegean Sea relative to 'pre-sapropel' conditions has been reconstructed (Kotthoff et al. 2008a). On the other hand, a significantly enhanced freshwater 
flux into the eastern Mediterranean Sea from the northern borderlands during sapropel formation has also been disputed (Osborne et al. 2010). In any event, future analyses of sapropel-correlative time slices from Tenaghi Philippon will serve to identify which patterns emerge for the hydrological regime in the northern borderlands of the Aegean Sea at times of sapropel formation and to what extent these patterns are a consistent feature of the Mediterranean climate system during the Quaternary.

While high-resolution palynological data covering the antepenultimate glacial (MIS 9a-c, 8 and 7; 312$240 \mathrm{ka} \mathrm{BP}$ ) have recently been published (Fletcher et al. 2013), equivalent analyses of MIS 7a-d and 6 are currently in progress. Upon completion, they will yield a palynological record of terrestrial climate and ecosystem dynamics in the eastern Mediterranean region during the last $\sim 312 \mathrm{ka}$ in unprecedented temporal resolution. As such, they will be instrumental in identifying the intervals and ultimately the boundary conditions for large-amplitude, short-term climate fluctuations beyond the range of Greenland ice cores; in particular, they will allow ground truthing of the synthetic record of millenial-scale Greenland climate variability as it has been constructed based on the thermal bipolar seesaw model (Barker et al. 2011).

\subsubsection{Macro- and cryptotephra layers}

The Tenaghi Philippon archive consists predominantly of peat, which is ideally suited to preserve inorganic solids supplied by atmospheric deposition (Shotyk et al. 1998), and is located within the dispersal regions of tephras from the Aegean and Italian volcanic provinces. As such, the archive holds great potential for establishing an integrated tephrostratigraphical scheme for the eastern Mediterranean region. The youngest part of the archive (comprising MIS 3-1) has long been known to preserve macrotephras that are important stratigraphic markers within the central and eastern Mediterranean region (compare Section 3). Specifically, these are the Y2, Y3, and Y5 tephras, today dated at $\sim 22, \sim 29$ and $\sim 39$ ka BP, respectively (Wulf et al. 2002, Pyle et al. 2006, Albert et al. 2015, compare Fig.5).

A pilot study carried out on the depth interval 15$6 \mathrm{~m}$ of the TP-2005 core (equivalent to $\sim 46-11 \mathrm{ka} \mathrm{BP}$; Müller et al. 2011) has revealed the presence of multiple cryptotephra layers, i.e., a much higher number of cryptotephras layers than visible tephra equivalents (Fig. 6). As has been the case with other paleo-records in the Mediterranean region (e.g., Bourne et al. 2010, Damaschke et al. 2013), this significantly increases the potential of Tenaghi Philippon as a recorder of volcanic events. The detection of these additional isochrons are of particular value because they, as with visible tephra layers, can be used to (i) directly import proximal or distal tephra ages (e.g., ${ }^{40} \mathrm{Ar} /{ }^{39} \mathrm{Ar}$ dates) where existent and (ii) allow synchronisation to other records where the same tephra has been registered. This can be achieved in distal localities via geochemical correlation of the volcanic glass component, specifically the measurement of major, minor and trace elements. Increasingly it is possible to gain these data even when analysing low numbers and small vol-
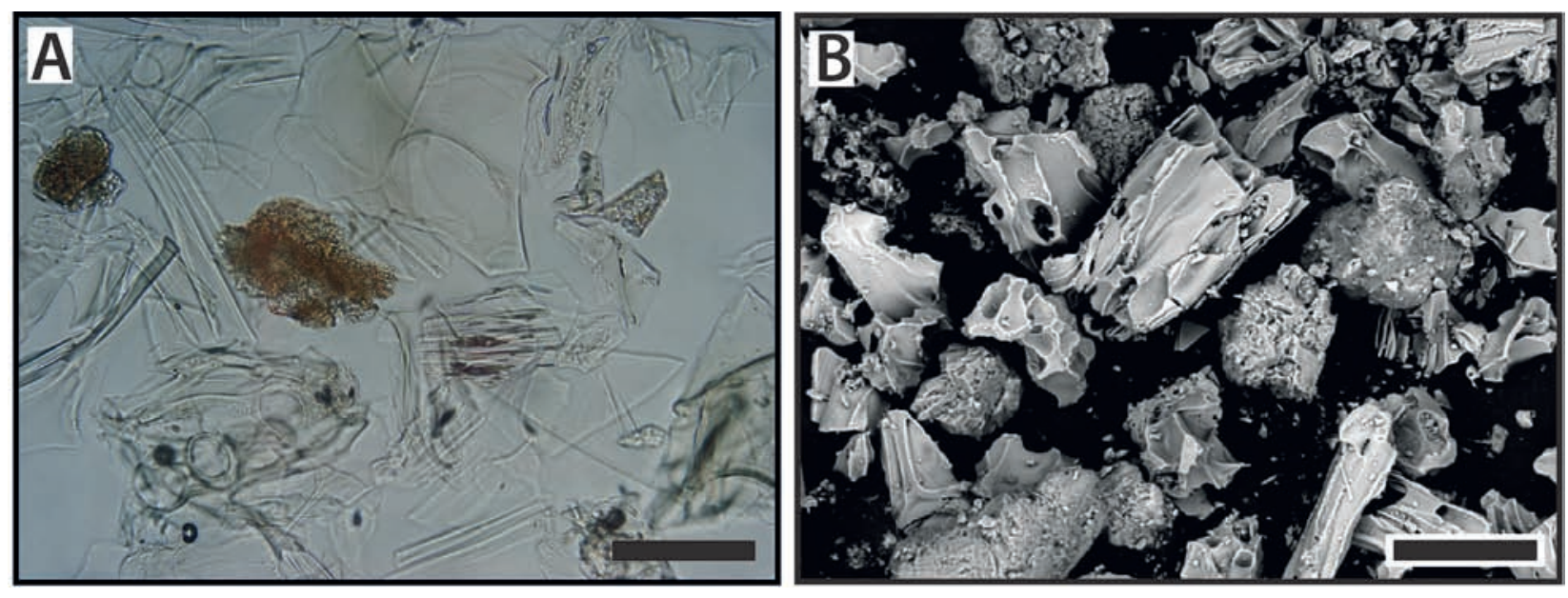

Fig. 5. Microphotographs of tephra shards from the TP-2005 core. Shown example is from the visible tephra layer at $12.87 \mathrm{~m}$ depth (Y-5 tephra). Note large fluted shards, platy cuspate shards and highly vesicular shards. A = Transmitted light microscopy, $\mathrm{B}=$ scanning electron microscopy. Black scale bars equal $100 \mu \mathrm{m}$. 

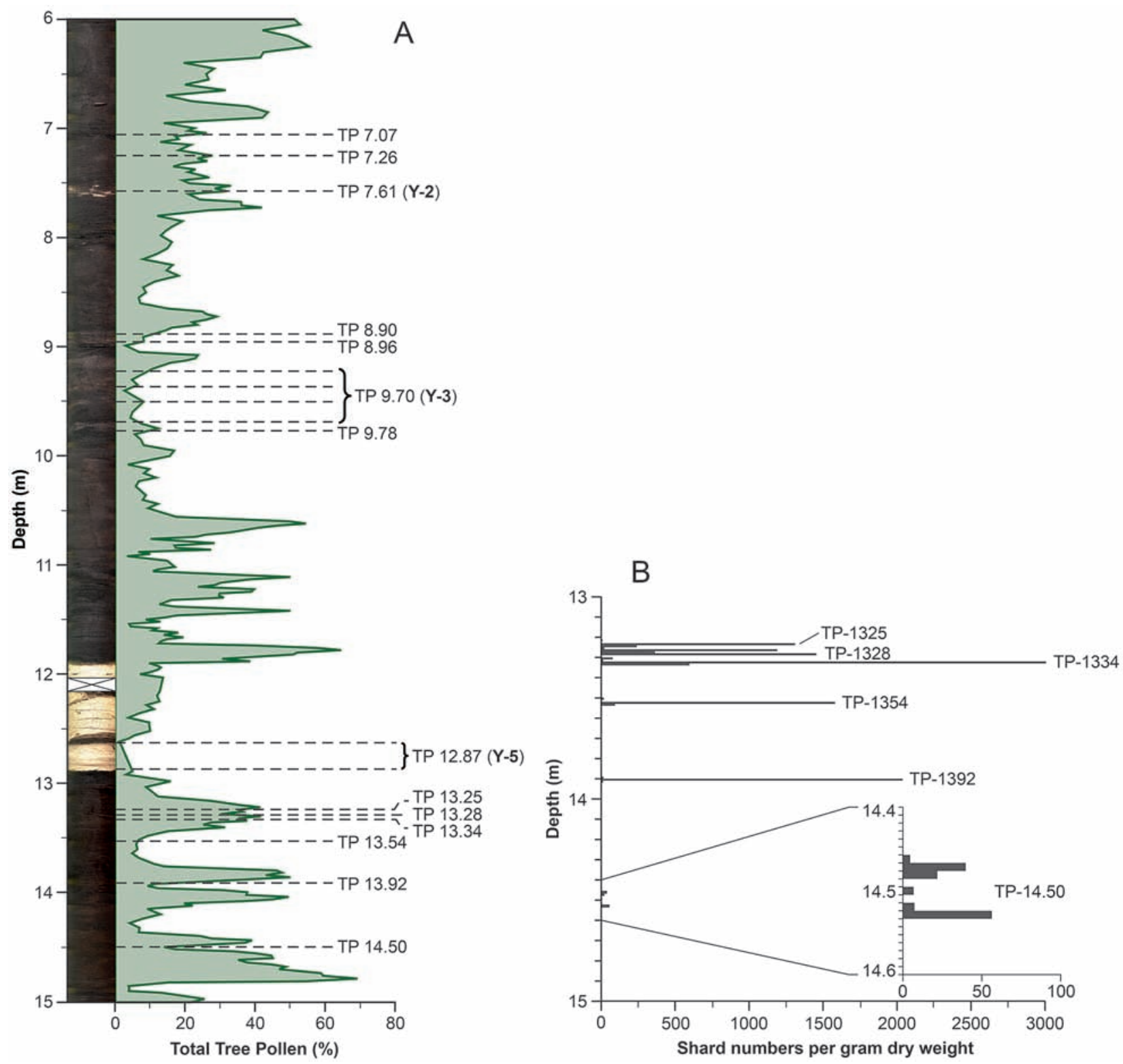

Fig. 6. Core photographs, total tree-pollen percentages, positions of macro- and microscropically visible tephra layers, and tephra shard counts for selected depth intervals of the TP-2005 core. (A) Depth interval 15-6 m below surface (corresponding to $\sim 45-11 \mathrm{ka} \mathrm{BP}$ ) with positions of macroscopically visible tephras and cryptotephras. Three published tephra layer correlations are also indicated: Y-2 (Cape Riva) (Müller et al. 2011), Y-3 (Albert et al.2015), and Y-5 (Campanian Ignimbrite) (Müller et al. 2011; Lowe et al. 2012). Total tree pollen percentages (Müller et al. 2011) are given for climatostratigraphic context. (B) Detail of depth interval 15-13 m, with shard numbers per gram of dry sediment for individual cryptotephra layers.

canic shards associated with cryptotephra layers (see Lowe 2011, and references within). For Tenaghi Philippon, this has been demonstrated recently by Albert et al. (2015); they have correlated a cryptotephra to proximal and distal volcanic units using both the more traditional Electron Probe Micro-Analysis method alongside Laser Ablation Inductively Coupled Plasma Mass Spectrometry and Secondary Ion Mass Spectro- metry, which allow trace element concentrations to be determined.

The cryptotephra layers were detected using the stepped density separation technique as advocated by Turney (1998), but with the modifications outlined by Blockley et al. (2005). Contiguous sediment samples were taken, physically and chemically processed, and visually analysed using a high-powered binocular 
microscope with cross-polarising filters. Tephra shard concentrations were calculated as shards per gram dry weight.

To date, only a small part of the Tenaghi Philippon archive has been analysed for cryptotephra content, and it is likely that a rich tephrostratigraphic record awaits to be uncovered in the older part of the sequence. This could make Tenaghi Philippon a key record in both augmenting and understanding the longer-term volcanic evolution of the Eastern Mediterranean region as well as allowing the environmental and temporal placement of key tephra layers.

\subsection{The 2009 coring campaign}

To analyze short-term climate and ecosystem variability in earlier (i.e., older than $\sim 312 \mathrm{ka} \mathrm{BP}$ ) intervals of the Quaternary, a second, larger-scale coring campaign was carried out at Tenaghi Philippon in 2009; its aim was to recover the remainder of the polleniferous sequence to a depth of $\sim 200 \mathrm{~m}$. Technologically, the drilling operations greatly benefitted from the experiences gained during the TP-2005 campaign. They had shown that a simple, pneumatic-hammer-driven system yielded high-quality cores in peat-dominated lithology only to a depth of $\sim 60 \mathrm{~m}$. Limiting factors were a decrease of the hammering force with depth, an increasing loss of the circulating water into the sidewall even when long-chained polymers were added, and, as a result of the latter, an increasing risk of the casing becoming stuck.

\subsubsection{On-site operations and core processing}

Drilling operations were carried out over five weeks in April and May 2009 at a site located $4.4 \mathrm{~km}$ and $1.0 \mathrm{~km}$ ESE of the TP-2005 and TF-II localities, respectively (coordinates: $40^{\circ} 57^{\prime} 39.5^{\prime \prime} \mathrm{N}, 24^{\circ} 16^{\prime} 03.1^{\prime \prime} \mathrm{E}, 40 \mathrm{~m}$ above sea level; Fig. 2). The drilling contractor GEOMECHANIK (Wohringen, Germany) used a RB 50 rotary drilling rig; the drilling technique comprised a $500-\mathrm{kg}$ hammer driving the probe into the sediment, overwashing with a rotating pipe to the base of the probe, and final retrievement of the sediment-filled probe. Bentonite, sodium carbonate and carboxymethyl cellulose were used as additives to the drilling fluid.

Immediately after recovery, the individual, 1-mlong core segments were stored at $\sim 4^{\circ} \mathrm{C}$. Core processing (including splitting into work and archive halves, lithological description, and photogrammetric scanning) was carried out at the International Ocean
Discovery Program (IODP) Core Repository, University of Bremen, Germany. The cores are now curated at the Biodiversity and Climate Research Center, Frankfurt, and the Institute of Earth Sciences, University of Heidelberg, at $-15^{\circ} \mathrm{C}$.

\subsubsection{First results and outlook}

The campaign yielded the core TP-2009, which has a recovery of $99.0 \%$ and spans the depth interval from 50 to $200 \mathrm{~m}$. Lithologically, the core consists predominantly of peat; from $\sim 171 \mathrm{~m}$ downcore, the sediment comprises primarily coarse-grained clastics in a clayey matrix. As a basis for further evaluation, a palynological skeleton diagram was produced at $0.5 \mathrm{~m}$ resolution based on 301 samples (Figs. 7, 8). The palynological preparation protocol was identical with that followed for the TP-2005 core (compare Section 4.1). An average of 510 pollen grains and spores were counted per sample; freshwater algae were also registered.

\subsubsection{Age control}

The age model presently available for core TP-2009 relies primarily on the visual correlation of key features in the arboreal pollen curve to the LR04 stack of benthic oxygen isotope records (Lisiecki and Raymo 2005) as shown in Fig. 7. This procedure is based on the fact that the pollen signals from the old TF-II and TF-III cores exhibit a close correlation with marine isotope stages (Wijmstra and Groenhart 1983, Tzedakis et al. 2006), an observation further substantiated for the late Quaternary through the high-resolution pollen data from the TP-2005 core as discussed above.

Additional stratigraphic information comes from the fact that sediment samples to a depth of at least $127.70 \mathrm{~m}$ exhibit normal polarization (E. Appel, pers.

Fig. 7. Comparison of the Tenaghi Philippon climate archive as represented by pollen data from the TP-2005 und TP-2009 cores with insolation and key climate records. (A) Eccentricity (Berger and Loutre, 1991); (B) Mid-June insolation at $65^{\circ} \mathrm{N}$ (Berger and Loutre 1991); (C) LR04 stack of benthic oxygen isotope records (Lisiecki and Raymo 2005); (D) Deuterium-based Antarctic surface temperature (EDC; Jouzel et al. 2007); (E) and (F) Overview treepollen records for Tenaghi Philippon cores TP-2005 (E; after Pross et al. 2007 and Müller et al. 2011) and TP-2009. Pollen percentages were calculated excluding pollen from aquatics and spores. Records (C) and (D) are plotted against their previously published chronologies, records (E) and (F) are plotted against core depths. 


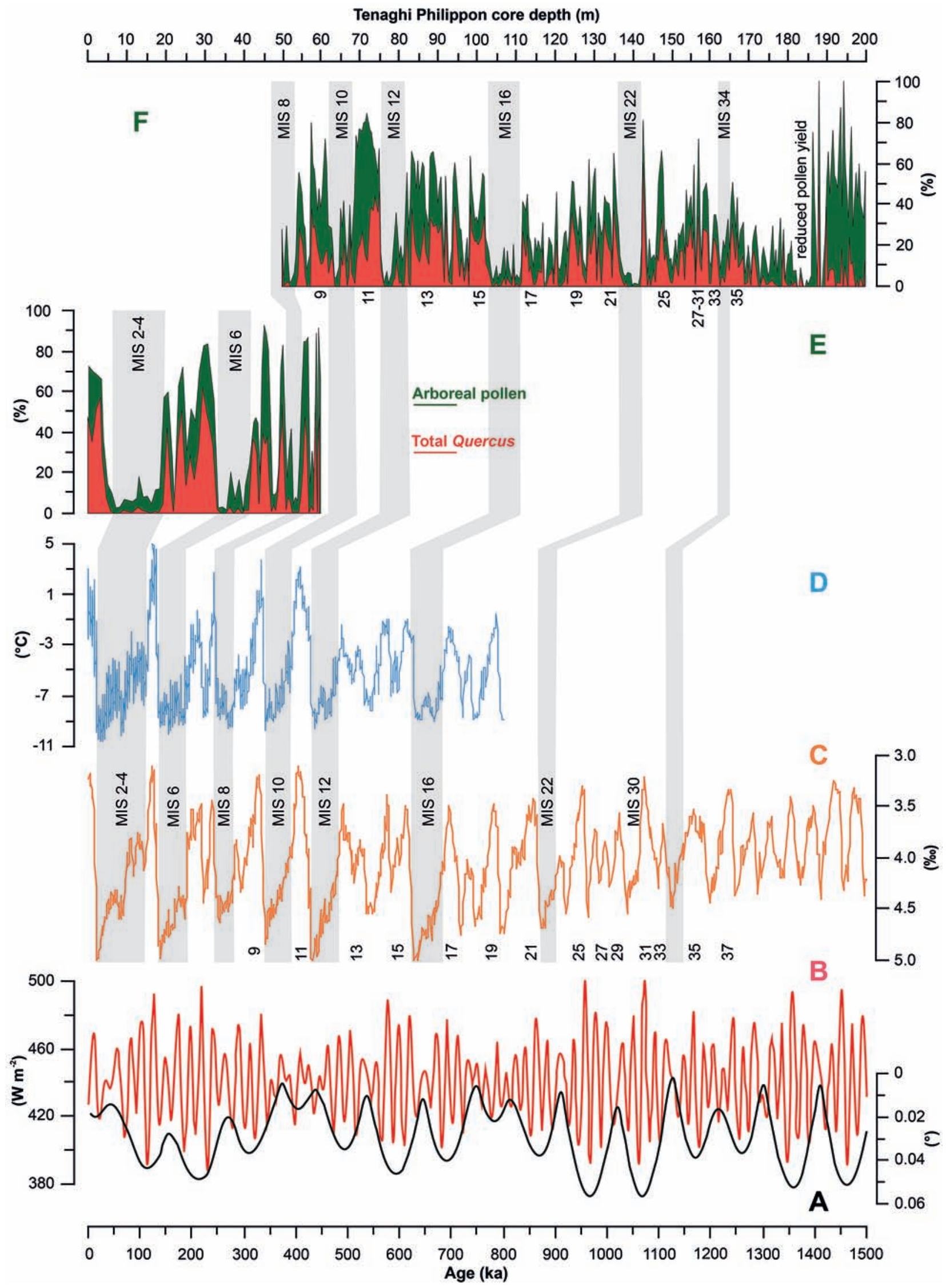




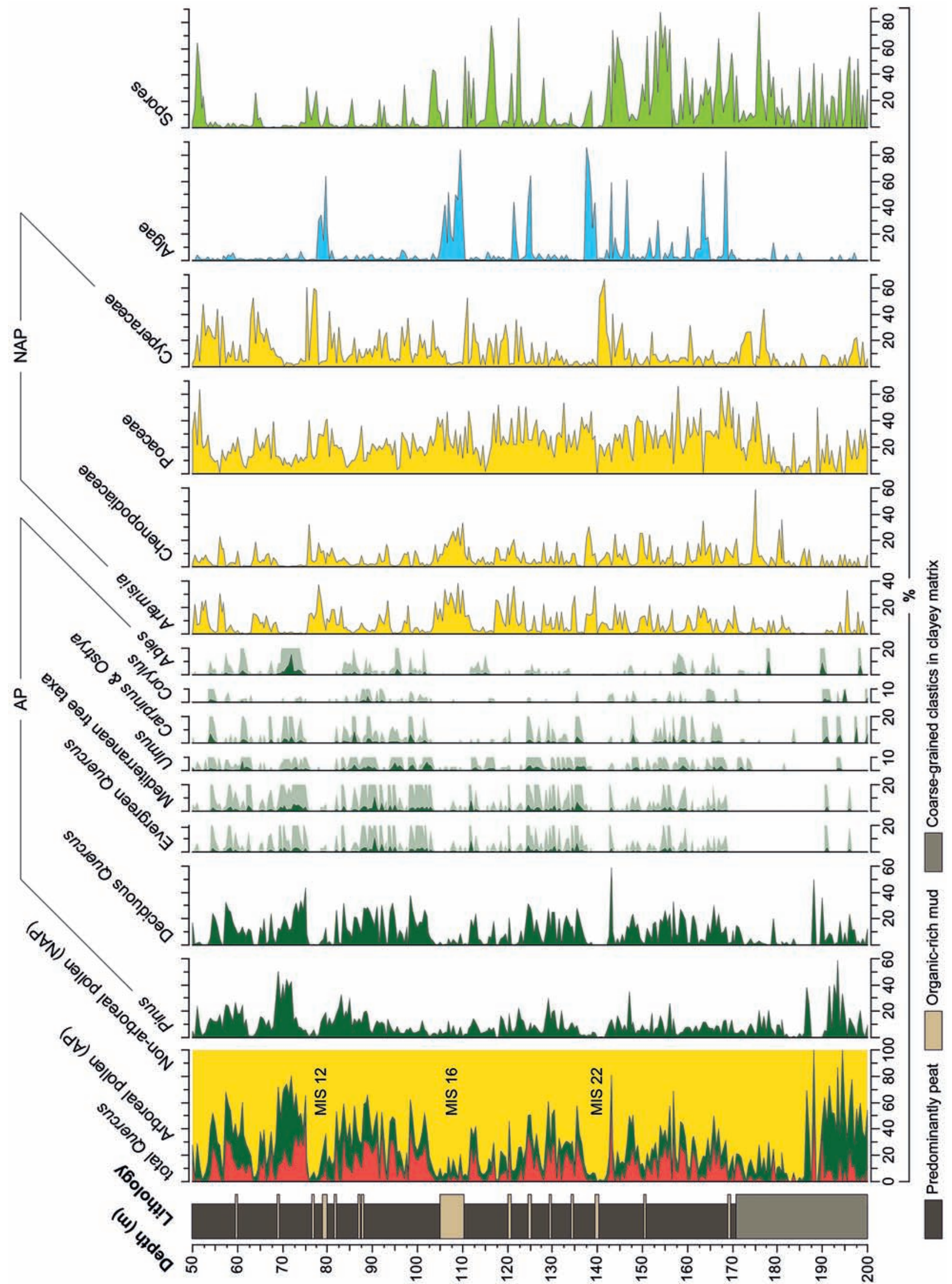


comm. 2014). This suggests that the core interval above this depth belongs to the Brunhes magnetochron. However, the interpretation of paleomagnetic reversals in the TP-2009 core as stratigraphic markers must take into consideration that the lock-in depth for the permanent acquisition of post-depositional remanent magnetization is located below the paleo-sediment/water interface where coeval signals from surface proxies such as pollen are deposited (compare Zhou and Shackleton 1999, Liu et al. 2008). Hence, paleomagnetic signals can apparently 'lead' bio- or climatostratigraphical signals of the same age in a given sedimentary archive. This effect has previously been described for the TF-III core, where the position of the Matuyama-Brunhes boundary $(\sim 773 \mathrm{ka}$ BP according to Channell et al. 2010; $786 \mathrm{ka}$ BP according to Sagnotti et al. 2014) is not preserved within the core interval representing the MIS 19 interglacial, but in the interval corresponding to MIS 20 (Tzedakis et al. 2006). Magnetostratigraphic work towards refining the exact positions of the Matuyama-Brunhes boundary and the Jaramillo event (1.07-0.99 Ma; Pillans and Gibbard 2012) in core TP 2009 is currently under way. Additional chronostratigraphic refinement will come from the analysis of microtephras as currently being performed for the TP-2005 core (compare Section 4.1). Besides yielding a unique record of volcanic activity and providing a step forward towards a better correlation of environmental archives in the Eastern Mediterranean region (compare Lowe et al. 2012), it will allow a precise splicing of the TP-2009 and TP2005 cores.

\subsubsection{Climatostratigraphical results}

Based on the millenial-scale temporal resolution as yet available, the TP-2009 pollen data record at least twelve glacial/interglacial cycles (MIS 8/9 to MIS $30 / 31$; Figs. 7,8 ) as well as a number of pronounced

Fig. 8. Simplified pollen record from Tenaghi Philippon based on the new TP-2009 core plotted against core depth. Semi-transparent curves indicate $10 x$ exaggerated percentages of selected taxa. The percentages of algae and fern spores were calculated relative to the pollen sum of terrestrial taxa. $\mathrm{AP}=$ arboreal pollen; NAP $=$ non-arboreal pollen; MIS = Marine Isotope Stage. The record is based on 301 samples. The extremely high AP values at 196.5, 194.5, 193.5 , and $188.0 \mathrm{~m}$ depth are likely due to low counting sums in the respective samples, which are from horizons with low pollen yield. stadials and interstadials. Although the exact temporal extent of the TP-2009 core remains to be determined, it is clear that the core documents climate and vegetation dynamics throughout the eccentricity-dominated '100-ka world' through the Middle Pleistocene Transition at least into the terminal part of the obliquitydominated '41-ka world'. In general, glacials/stadials were characterized by steppe biomes dominated by Artemisia and Chenopodiaceae; deciduous tree taxa occurred only in low numbers, and frost-sensitive Mediterranean tree taxa such as evergreen Quercus were almost constantly absent. Moreover, strong glacials (such as MIS 22, 16 and 12) exhibit high abundances of freshwater algae (Botryococcus, Coelastrum, Pediastrum, Zygnemataceae) (Fig. 8). In contrast, interglacials/interstadials were characterized by pronounced forest expansions, with temperate and Mediterranean broadleaved/evergreen tree taxa being most abundant during intervals of large forest population size.

Below $\sim 175 \mathrm{~m}$, the regular pattern of glacial/interglacial cycles as documented in the pollen data for further upcore is less clear. A number of samples below $\sim 188 \mathrm{~m}$ (i.e., at 196.5, 194.5, 193.5, and $188.0 \mathrm{~m}$ ) exhibit extremely high arboreal pollen (AP) percentages (Fig. 8). These values partially exceed the maximum AP percentages reached elsewhere in the record and can probably be attributed to the low counting sums in the respective samples, which are from horizons with low pollen yield.

Between $\sim 190 \mathrm{~m}$ and $\sim 175 \mathrm{~m}$, percentages of nonarboreal pollen remain at high levels typical of glacial intervals further upcore; pollen from Mediterranean tree taxa are almost constantly absent (Fig. 8). A similar pattern is evident in the original pollen data from the depth interval $\sim 191 \mathrm{~m}$ to $\sim 176 \mathrm{~m}$ in core TF-III, i.e., pollen zone 46 of Van der Wiel and Wijmstra (1987b). These authors consider the pollen assemblages from this interval to represent a different vegetation composition and succession, with an overrepresentation of local elements, than observed further upcore; they ascribe the differences to a tectonically induced prevalence of a fluvial rather than a limnic or telmatic depositional setting. A higher-energy depositional regime, with a higher sedimentation rate than further upcore, is documented by the presence of coarse-grained clastics and the frequent occurrence of reworked 'Tertiary' pollen types in the respective intervals of both the TF-III and TP-2009 cores. Additional support for a high sedimentation rate, which would have caused a 'stretching' of the respective 
pollen record in comparison to further upcore, is invoked by Van der Wiel and Wijmstra (1987b) by their interpretation that the Jaramillo subchron (1068$987 \mathrm{ka}$ BP; Channell et al. 2002) encompasses the depth interval from 210 to $195 \mathrm{~m}$ in the TF-III core; this interpretation, which was also adopted by Mommersteeg et al. (1995), yields a sedimentation rate of $\sim 0.2 \mathrm{~m} / \mathrm{ka}$. However, Van der Wiel and Wijmstra (1987b) also emphasize that the TF-III core yielded only very weak paleomagnetic signals, which renders it difficult to confidently identify the position of the Jaramillo subchron.

In an effort to climatostratigraphically reconcile the pollen data of Van der Wiel and Wijmstra (1987b) from the respective core part with variations in global ice volume as documented in the benthic oxygen isotope record, Tzedakis et al. (2006) applied an orbital tuning procedure to the original pollen data; notably, they excluded the presumed top of the Jaramillo subchron in the TF-III core as a magnetostratigraphic control point. This procedure yields a close correspondence of the tree-pollen curve with the marine isotope stratigraphy extending to MIS $44(\sim 1.35 \mathrm{Ma})$. As a secondary effect, it results in a sedimentation rate for the clastics-dominated core interval of $\sim 0.2 \mathrm{~m} / \mathrm{ka}$, which agrees with the original assumption of Van der Wiel and Wijmstra (1987b) based on their presumed position and extent of the Jaramillo subchron in the TF-III core. Given the high degree of agreement between the TF-III and TP-2009 cores as it emerges from the available palynological and sedimentological data, the TP-2009 core allows the two scenarions outlined above to be tested, with important implications for the age/depth relationship and consequently the temporal extent of the polleniferous succession in the deep subsurface of the Philippi peatland. If the tuning procedure of Tzedakis et al. (2006) is correct, the Jaramillo subchron should be located within the depth interval from 160 to $157 \mathrm{~m}$ in the TF-III core and, by extension, at similar depths in the TP-2009 core.

\subsubsection{Ongoing work and perspectives \\ for future studies}

In light of the apparent stratigraphic completeness of the Tenaghi Philippon archive, exceptional bioclimatic sensitivity of the Tenaghi Philippon site and high core recovery rates of the TP-2005 and TP-2009 drilling campaigns, the new cores from Tenaghi Philippon have great potential for an advanced reconstruction of terrestrial climate and ecosystem dynamics in the eastern Mediterranean region spanning from the early
Pleistocene into the Holocene. With a minimum age of $\sim 1.1 \mathrm{Ma}$, the cores cover the full range of climatic boundary conditions from the late obliquity-dominated '41-ka world' throughout the Middle Pleistocene Transition and ultimately the eccentricity-dominated '100-ka world'. In particular, they can yield insights into the development of decadal- to centennial-scale climate and ecosystem dynamics at one location, thereby allowing to circumvent uncertainties as they would arise through the stacking of shorter-term records from multiple locations.

These features guarantee the new cores from Tenaghi Philippon a prominent position among the highquality terrestrial climate records recently retrieved from the greater eastern Mediterranean region, such as Sofular cave ( $670 \mathrm{ka}$; Badertscher et al. 2011), Soreq and Peqiin caves ( $250 \mathrm{ka}$; Bar-Matthews et al. 2003), Lake Van ( $600 \mathrm{ka}$; Litt et al. 2014, Stockhecke et al. 2014), Dead Sea ( 240 ka; Neugebauer et al. 2014), Yammouneh Basin ( $400 \mathrm{ka}$; Gasse et al. 2015), and Lake Ohrid ( $>1.2 \mathrm{Ma}$; Wagner et al. 2014). At the same time, the integration of data from these terrestrial key records with datasets from marine drillcores from the eastern Mediterranean Sea (e.g., Kroon et al. 1998, Ziegler et al. 2010, Konijnendijk et al. 2014, Rohling et al. 2014) will ultimately yield a spatially resolved understanding of climate dynamics in the greater eastern Mediterranean region for 'deeper-time' intervals of the Quaternary, significantly extending beyond the last glacial/interglacial cycle. Such a framework of climate and ecosystem data will also assist paleoanthropologists in resolving the dispersal dynamics and migration corridors of archaic and modern humans from Africa into Eurasia.

The chronology for the TP-2009 core is currently being refined through magneto- and tephrostratigraphy. Also ongoing are paleoclimatically oriented studies of the core material comprising palynology, stableisotope geochemistry, organic geochemistry, and coal petrology. Upon completion, they will yield new insights into the characteristics of short-term (decadalto centennial-scale) climate variability and their impact on terrestrial environments in the eastern Mediterranean region.

Acknowledgements. Invaluable support was provided by Theodoros Kalliontzis, Andreas Balikas and Constantinos Tsompanoglou, Prefecturer, Vice-Prefecturer and Director of the Kavala Prefecture at the time of both coring campaigns, respectively, as well as by Nikos Nikolaidis. Ursula Röhl, Walter Hale, and Alex Wülbers are thanked for providing access to the facilities of MARUM and the IODP 
Core Repository, University of Bremen. Discussions with Henry Hooghiemstra and Klaus Reicherter, and the constructive comments of two anonymous reviewers are gratefully acknowledged. Erwin Appel and Susanne Liner provided support in paleomagnetic analyses and palynological processing, respectively. Suzanne MacLachlan supplied scanning electron photomicrographs of the Y-5 tephra. Wilhelm Püttmann granted access to cold-storage facilities. Funding was granted by the German Research Foundation, the Wilhelm Schuler Foundation, and the Biodiversity and Climate Research Center Frankfurt (Germany) to JP, and by The Royal Society and the Natural Environment Research Council (NERC; United Kingdom) to PCT. MH was supported by NERC through a grant awarded to the RESET consortium.

\section{References}

Albert, P.G., Hardiman, M., Keller, J., Tomlinson, E.L., Bourne, A.J., Smith, V.C., Wulf, S., Zanchetta, G., Sulpizio, R., Müller, U.C., Pross, J., Ottolini, L., Matthews, I.P., Blockley, S.P.E., Menzies, M.A., 2015. Revisiting the Y-3 tephrostratigraphic marker: new diagnostic glass geochemistry, improved age estimate and climatostratigraphical context. Quaternary Science Reviews 118, 105121.

Alley, R.B., Marotzke, J., Nordhaus, W.D., Overpeck, J.T., Peteet, D.M., Pielke Jr., R.A., Pierrehumbert, R.T., Rhines, P. B., Stocker, T.F., Talley, L. D., Wallace, J.M., 2003. Abrupt climate change. Science 299, 2005-2010.

Badertscher, S., Fleitmann, D., Cheng, H., Edwards, R.L., Göktürk, O. M., Zumbühl, A., Leuenberger, M., Tüysüz, O., 2011. Pleistocene water intrusions from the Mediterranean and Caspian seas into the Black Sea. Nature Geoscience 4, 236-239.

Barker, S., Knorr, K., Edwards, R.L., Parrenin, F., Putnam, A.E., Skinner, L.C., Wolff, E., Ziegler, M., 2011. 800,000 years of abrupt climate variability. Science 334, 347-351.

Bar-Matthews, M., Ayalon, A., Gilmour, M., Matthews, A., Hawkesworth, C. J., 2003. Sea-land isotopic relationships from planktonic foraminifera and speleothems in the Eastern Mediterranean region and their implication for paleorainfall during interglacial intervals. Geochimica et Cosmochimica Acta 67, 3181-3199.

Benazzi, S., Douka, K., Fornai, C., Bauer, C.C., Kullmer, O., Svoboda, J., Pap, I., Mallegni, F., Bayle, P., Coquerelle, M., Condemi, S., Ronchitelli, A., Harvati, K., Weber, G. W., 2011. Early dispersal of modern humans in Europe and implications for Neanderthal behaviour. Nature 479, 525-528.

Berger, A., Loutre, M.F., 1991. Insolation values for the climate of the last 10 million years. Quaternary Science Reviews 10, 297-317.

Blockley, S.P.E., Pyne-O’Donnell, S.D.F., Lowe, J.J., Matthews, I. P., Stone, A., Pollard, A. M., Turney, C. S. M.,
Molyneux, E. G., 2005. A new and less destructive laboratory procedure for the physical separation of distal glass tephra shards from sediments. Quaternary Science Reviews 24, 1952-1960.

Bond, G.C., Kromer, B., Beer, J., Muscheler, R., Evans, M.N., Showers, W., Hoffmann, S., Lotti-Bond, R., Hajdas, I., Bonani, G., 2001. Persistent solar influence on North Atlantic climate during the Holocene. Science 294, 2130-2136.

Bond, G.C., Showers, W. J., Cheseby, M., Lotti, R., Almasi, P., deMenocal, P., Priore, P., Cullen, H., Hajdas, I., Bonani, G., 1997. A pervasive millennial-scale cycle in North Atlantic Holocene and glacial climates. Science 278, 1257-1266.

Bornovas, J., Rondongianni-Tsiambaou, T., 1983. Geological Map of Greece, 1:500,000. Institute of Geology and Mineral Exploration, Athens, Greece.

Bourne, A., Lowe, J.J., Trincardi, F., Asioli, A., Blockley, S.P.E., Wulf, S., Matthews, I.P., Piva, A., Vigliotti, L., 2010. Distal tephra record for the last ca 105,000 years from core PRAD 1-2 in the central Adriatic Sea: implications for marine tephrostratigraphy. Quaternary Science Reviews 29, 3079-3094.

Brauer, A., Allen, J. R. M., Mingram, J., Dulski, P., Wulf, S., Huntley, B., 2007. Evidence for last interglacial chronology and environmental change from Southern Europe. Proceedings of the National Academy of Science of the USA 104, 450-455.

Broussoulis, J., Yiakkoupis, P., Arapoyiannis, E., Anastasiadis, J., 1991. The Drama lignite deposit: Geological study. IGME Internal Report, Athens, 81 pp. [in Greek].

Channell, J.E.T., Hodell, D. A., Singer, B.S., Xuan, C., 2010. Reconciling astrochronological and ${ }^{40} \mathrm{Ar} /{ }^{39} \mathrm{Ar}$ ages for the Matuyama-Brunhes boundary and late Matuyama chron. Geochemistry, Geophysics, Geosystems 11, Q0AA12.

Channell, J.E. T., Mazaud, A., Sullivan, S., Turner, S., Raymo, M.E., 2002. Geomagnetic excursions and paleointensities in the Matuyama chron at Ocean Drilling Program Sites 983 and 984 (Iceland Basin). Journal of Geophysical Research 107, Art. Nr. 2114.

Christanis, K., 1983. Genese und Fazies der Torf-Lagerstätte von Philippi (Griechisch-Mazedonien) als Beispiel der Entstehung einer Braunkohlen-Lagerstätte vom stark telmatischen Typ. PhD thesis, University of Braunschweig, 170 pp.

Christanis, K., Georgakopoulos, A., Fernández-Turiel, J.L., Bouzinos, A., 1998. Geological factors influencing the concentration of trace elements in the Philippi peatland, eastern Macedonia, Greece. International Journal of Coal Geology 36, 295-313.

Commission of the European Communities, 2008. Commission decision of 5 March 2008 on the granting or maintaining in force by the Hellenic Republic of rights in favour of Public Power Corporation S.A. for extraction of lignite. Brussels, Belgium.

Dafis, S., Papastergiadou, E., Georghiou, K., Babalonas, D., Georgiadis, T., Papageorgiou, M., Lazaridou, T., Tsiaoussi, V., 1997. Directive 92/43/EEC: The Project "Habitat" 
in Greece: Network Natura 2000. DG XI Commission of the European Communities - Goulandris Museum of Natural History - Greek Biotope/Wetland Center, Athens, Greece.

Damaschke, M., Sulpizio, R., Zanchetta, G., Wagner, B., Böhm, A., Nowaczyk, N., Rethemeyer, J., Hilgers, A., 2013. Tephrostratigraphic studies on a sediment core from Lake Prespa in the Balkans. Climate of the Past 9, 267-287.

Dansgaard, W., Johnsen, S.J., Clausen, H.B., Dahljensen, D., Gundestrup, N. S., Hammer, C.U., Hvidberg, C.S., Steffensen, J.P., Sveinbjornsdottir, A.E., Jouzel, J., Bond, G., 1993. Evidence for general instability of past climate from a 250-kyr ice-core record. Nature 364, 218220.

Debret, M., Bout-Roumazeilles, V., Grousset, F., Desmet, M., McManus, J.F., Massei, N., Sebag, D., Petit, J.-R., Copard, Y., Trentesaux, A., 2007. The origin of the 1500year climate cycles in Holocene North-Atlantic records. Climate of the Past 3, 569-575.

Del Moro, A., Kyriakopoulos, K., Pezzino, A., Atzori, P., Lo Giudice, A., 1990. The metamorphic complex associated to the Kaval plutonites: A Rb-Sr geochronological, petrological and structural study. Geologica Rhodopica 2, 143-156.

Dotsika, E., Lykoudis, S., Poutoukis, D., 2010. Spatial distribution of the isotopic composition of precipitation and spring water in Greece. Global and Planetary Change 71, 141-149.

Dumurdzanov, N., Serafimovski, T., Burchfiel, B.C., 2005. Cenozoic tectonics of Macedonia and its relation to the South Balkan extensional regime. Geosphere 1, 1-22.

Eleftheriadis, G., Lippolt, H.J., 1984. Alterbestimmungen zum oligozänen Vulkanismus der Süd-Rhodopen, NordGriechenland. Neues Jahrbuch für Geologie und Paläontologie, Monatshefte 3, 179-191.

EPICA community members, 2004. Eight glacial cycles from an Antarctic ice core. Nature 429, 623-628.

Filippidis, A., Georgakopoulos, A., Kassoli-Fournaraki, A., Misaelides, P., Yiakkoupis, P., Broussoulis, J., 1996. Trace element contents in composited samples of three lignite seams from the central part of the Drama lignite deposit, Macedonia, Greece. International Journal of Coal Geology 29, 219-234.

Fleitmann, D., Cheng, H., Badertscher, S., Edwards, R.L., Mudelsee, M., Gokturk, O.M., Fankhauser, A., Pickering, R., Raible, C.C., Matter, A., Kramers, J., Tuysuz, O., 2009. Timing and climatic impact of Greenland interstadials recorded in stalagmites from northern Turkey. Geophysical Research Letters 36, L19707.

Fletcher, W. J., Müller, U.C., Koutsodendris, A., Christanis, K., Pross, J., 2013. A centennial-scale record of vegetation and climate variability from 312 to $240 \mathrm{ka}$ (Marine Isotope Stages 9c-a, 8 and 7e) from Tenaghi Philippon, NE Greece. Quaternary Science Reviews 78, 108-125.

Flocas, A.A., Angouridakis, V.E., 1979. Extreme values analysis of air temperature over Greece. Archiv für Meteorologie, Geophysik und Bioklimatologie 27, 47-57.
Florschütz, F., Menéndez Amor, J., Wijmstra, T. A., 1971. Palynology of a thick Quaternary succession in southern Spain. Palaeogeography, Palaeoclimatology, Palaeoecology 10, 233-264.

Follieri, M., Magri, D., Sadori, L., 1988. 250,000 year pollen record from Valle di Castiglione (Roma). Pollen et Spores 30, 329-356.

Gasse, F., Vidal, L., Van Campo, E., Demory, F., Develle, A.-L., Tachikawa, K., Elias, A., Bard, E., Garcia, M., Sonzogni, C., Thouveny, N., 2015. Hydroclimatic changes in northern Levant over the past 400,000 years. Quaternary Science Reviews 111, 1-8.

Georgakapoulos, A., Femández-Turiel, J.L., Christanis, K., Kalaitzidis, S., Kassoli-Foumaraki, A., Llorens, J. F., Filippidis, A., Gimeno, D., 2001. The Drama basin water: quality and peat/lignite interaction. Environmental Geology 41, 121-127.

Grachev, A.M., Severinghaus, J.P., 2005. A revised +10 $\pm 4^{\circ} \mathrm{C}$ magnitude of the abrupt change in Greenland temperature at the Younger Dryas termination using published GISP2 gas isotope data and air thermal diffusion constants. Quaternary Science Reviews 24, 513-519.

Gramann, F., Kockel, F., 1969. Das Neogen im Strimonbecken (Griechisch Ostmazedonien). Geologisches Jahrbuch 87, 445-484.

Greig, J.R. A., Turner, J., 1974. Some pollen diagrams from Greece and their archaeological significance. Journal of Archaeological Science 1, 177-194.

Higham, T. F. G., Compton, T., Stringer, C., Jacobi, R., Shapiro, B., Trinkaus, E., Chandler, B., Gröning, F., Collins, C., Hillson, S., O'Higgins, P., FitzGerald, C., Fagan, M., 2011. The earliest evidence for anatomically modern humans in northwestern Europe. Nature 479, 521-524.

Hoffmann, N., Reicherter, K., Fernández-Steeger, T., Grützner, C., 2010. Evolution of ancient Lake Ohrid: a tectonic perspective. Biogeosciences 7, 3377-3386.

Hublin, J.-J., 2014. The modern colonization of western Eurasia: when and where? Quaternary Science Reviews, http://dxdoi.org/10.1016/j.quascirev.2014.08.011.

Intergovernmental Panel on Climate Change, 2013: Annex I: Atlas of Global and Regional Climate Projections [van Oldenborgh, G.J., Collins, M., Arblaster, J., Christensen, J. H., Marotzke, J., Power, S.B., Rummukainen, M., Zhou, T. (Eds.)]. In: Climate Change 2013: The Physical Science Basis. Contribution of Working Group I to the Fifth Assessment Report of the Intergovernmental Panel on Climate Change [Stocker, T.F., Qin, D., Plattner, G.-K., Tignor, M., Allen, S. K., Boschung, J., Nauels, A., Xia, Y., Bex, V., Midgley, P.M. (Eds.)]. Cambridge University Press, Cambridge, United Kingdom.

Jouzel, J., Masson-Delmotte, V., Cattani, O., Dreyfus, G., Falourd, S., Hoffmann, G., Minster, B., Nouet, J., Barnola, J.M., Chappellaz, J., Fischer, H., Gallet, J.C., Johnsen, S., Leuenberger, M., Loulergue, L., Luethi, D., Oerter, H., Parrenin, F., Raisbeck, G., Raynaud, D., Schilt, A., Schwander, J., Selmo, E., Souchez, R., Spahni, R., Stauffer, B., Steffensen, J.P., Stenni, B., Stocker, T.F., Tison, J.L., Werner, M., Wolff, E.W., 2007. Orbital and 
millennial Antarctic climate variability over the past 800,000 years. Science 317, 793-796.

Kalaitzidis, S., 2007. Peat formation and evolution of peatlands in Greece. PhD thesis, University of Patras, 532 pp. [in Greek]

Kalaitzidis, S., Christanis, K., 2002. Mineral matter in the Philippi peat in relation to peat/lignite-forming conditions in Greece. Energy Sources 24, 69-81.

Kalaitzidis, S., Christanis, K., 2004. Peat petrography as a tool to interpret peat-accumulation features - case studies from Greece. In Päivänen, J. (Ed.), Wise use of Peatlands. Proceedings $12^{\text {th }}$ International Peat Congress, June 2004, Tampere, Finland, 1, 42-47.

Kalaitzidis, S., Georgakopoulos, A., Christanis, K., Iordanidis, A., 2006. Early coalification features as approached by solid-state ${ }^{13} \mathrm{C}$ CPMAS NMR spectroscopy. Geochimica et Cosmochimica Acta 70, 947-959.

Kaouras, G., Antoniadis, P., Blickwede, H., Riegel, W., 1991. Petrographische und palynologische Untersuchungen an Braunkohlen im Becken von Drama, Ostmakedonien (Griechenland). Neues Jahrbuch für Geologie und Paläontologie, Monatshefte 3, 145-162.

Karagiannakidou, V., Kokkini, S., 1987. The flora of Mount Menikion in North East Greece. Phyton 27, 267-283.

Karagiannakidou, V., Kokkini, S., 1988. Vegetation and altitudinal zones of Mount Menikion, NE Greece. Botanica Helvetica 98, 149-160.

Karagiannakidou, V., Konstantinou, M., Papademetriou, K., 1995. Floristic and phytogeographical research on the upper montane and the subalpine grassland flora of East Macedonia, Greece. Feddes Repertorium 106, 193-213.

Kilias, A., Mountrakis, D., 1990. Kinematics of the crystalline sequences in the western Rhodope Massif. Geologica Rhodopica 2, 100-116.

Konijnendijk, T.Y.M., Ziegler, M., Lourens, L.J., 2014. Chronological constraints on Pleistocene sapropel depositions from high-resolution geochemical records of ODP Sites 967 and 968. Newsletters on Stratigraphy 47, 263282.

Kotthoff, U., Koutsodendris, A., Pross, J., Schmiedl, G., Bornemann, A., Marino, G., Peyron, O., Schiebel, R., 2011. Impact of Lateglacial cold events on the northern Aegean region reconstructed from marine and terrestrial proxy data. Journal of Quaternary Science 26, 86-96.

Kotthoff, U., Pross, J., Müller, U.C., Peyron, O., Schmiedl, G., Schulz, H., Bordon, A., 2008a. Climate dynamics in the borderlands of the Aegean Sea during formation of Sapropel S1 deduced from a marine pollen record. Quaternary Science Reviews 27, 832-845.

Kotthoff, U., Müller, U.C., Pross, J., Schmiedl, G., Lawson, I. T., van de Schootbrugge, B., Schulz, H., 2008b. Lateglacial and Holocene vegetation dynamics in the Aegean region: An integrated view based on pollen data from marine and terrestrial archives. The Holocene 18, 10191032 .

Koukouzas, C., Foscolos, A.E., Kotis, T., 1997. Research and exploration of coal in Greece: A view to the future. Energy Source 19, 335-347.
Koutsodendris, A., Pross, J., Müller, U.C., Brauer, A., Fletcher, W. J., Kühl, N., Kirilova, E., Verhagen, F. T.M., Lücke, A., Lotter, A.F., 2012. A short-term climate oscillation during the Holsteinian interglacial (MIS 11c): An analogy to the $8.2 \mathrm{ka}$ climatic event? Global and Planetary Change 92, 224-235.

Kroon, D., Alexander, I., Little, M., Lourens, L. J., Matthewson, A., Robertson, A. H. F., Sakamoto, T., 1998. Oxygen isotope and sapropel stratigraphy in the eastern Mediterranean during the last 3.2 million years. In: Robertson, A.H.F., Emeis, K.-C., Richter, C., Camerlanghi, A. (Eds.), Proceedings of the Ocean Drilling Program, Scientific Results 160, 181-190.

Lavrentiadis, G., 1956. Investigation of the higher water and fen flora of Greek Macedonia. PhD thesis, University of Thessaloniki, $88 \mathrm{pp}$. [in Greek]

Leroy, S.A.G., Arpe, K., Mikolajewicz, U., 2011. Vegetation context and climatic limits of the Early Pleistocene hominin dispersal in Europe. Quaternary Science Reviews 30, 1448-1463.

Lionello, P., Abrantes, F., Gacic, M., Planton, S., Trico, R., Ulbrich, U., 2014. The climate of the Mediterranean region: research progress and climate change impacts. Regional Environmental Change 14, 1679-1684.

Lionello, P., Malanotte-Rizzoli, P., Boscolo, R., Alpert, P., Artale, V., Li, L., Luterbacher, J., May, W., Trigo, R., Tsimplis, M., Ulbrich, U., Xoplaki, E., 2006. The Mediterranean climate: An overview of the main characteristics and issues. In: Lionello, P., Malanotte-Rizzoli, P., Boscolo, R. (Eds.), Mediterranean climate variability. Elsevier, Amsterdam, pp. 1-26.

Lisiecki, L.E., Raymo, M.E., 2005. A Pliocene-Pleistocene stack of 57 globally distributed benthic $\delta^{18} \mathrm{O}$ records. Paleoceanography 20, PA1003.

Litt, T., Pickarski, N., Heumann, G., Stockhecke, M., Tzedakis, P. C., 2014. A 600,000 year long continental pollen record from Lake Van, eastern Anatolia (Turkey). Quaternary Science Reviews 104, 30-41.

Liu, Q.S., Roberts, A.P., Rohling, E.J., Zhu, R.X., Sun, Y.B., 2008. Post-depositional remanent magnetization lock-in and the location of the Matuyama-Brunhes geomagnetic reversal boundary in marine and Chinese loess sequences. Earth and Planetary Science Letters 275, 102110.

Lowe, D. J., 2011. Tephrochronology and its application: A review. Quaternary Geochronology 6, 107-153.

Lowe, J., Barton, N., Blockley, S., Ramsey, C.B., Cullen, V.L., Davies, W., Gamble, C., Grant, K., Hardiman, M., Housle, R., Lane, C.S., Lee, S., MacLeod, A., Menzies, M., Müller, W., Pollard, M., Price, C., Roberts, A.P., Rohling, E.J., Satow, C., Smith, V.C., Stringer, C.B., Tomlinson, E.L., White, D., Barker, G., Boric, D., Carandente, A., Ferrier, C., Guadelli, J.-L., Karkanas, P., Müller, U.C., Orsi, G., Pross, J., Rosi, M., Sirakov, N., Tzedakis, P.C., 2012. Volcanic layers illuminate the resilience of Neanderthals and early modern Humans to natural hazards. Proceedings of the National Academy of Science of the USA 109, 13532-13537. 
Martrat, B., Grimalt, J.O., Lopez-Martinez, C., Cacho, I., Sierro, F.J., Flores, J.A., Zahn, R., Canals, M., Curtis, J. H., Hodell, D. A., 2004. Abrupt temperature changes in the western Mediterranean over the past 250,000 years. Science 306, 1762-1765.

Martrat, B., Grimalt, J.O., Shackleton, N.J., de Abreu, L., Hutterli, M.A., Stocker, T.F., 2007. Four climate cycles of recurring deep and surface water destabilizations on the Iberian margin. Science 317, 502-507.

Melidonis, N., 1981. Beitrag zur Kenntnis der Torflagerstätte von Philippi (Ostmazedonien). Telma 11, 41-63.

Milner, A.M., Collier, R.E.L., Roucoux, K.H., Müller, U.C., Pross, J., Christanis, K., Tzedakis, P.C., 2012. Enhanced seasonality of precipitation in the Mediterranean during the early part of the Last Interglacial. Geology 40, 919-922.

Milner, A.M., Müller, U.C., Roucoux, K.H., Collier, R.E.L., Pross, J., Kalaitzidis, S., Christanis, K., Tzedakis, P.C., 2013. Environmental variability during the Last Interglacial: A new high-resolution pollen record from Tenaghi Philippon, Greece. Journal of Quaternary Science 28, 113117.

Mommersteeg, H. J.P.M., Loutre, M. F., Young, R., Wijmstra, T.A., Hooghiemstra, H., 1995. Orbital forced frequencies in the 975,000 year pollen record from Tenaghi Philippon (Greece). Climate Dynamics 11, 4-24.

Müller, U. C., Klotz, S., Geyh, M. A., Pross, J., Bond, G. C., 2005. Cyclic climate fluctuations during the last interglacial in central Europe. Geology 33, 449-452.

Müller, U.C., Pross, J., 2007. Lesson from the past: Present insolation minimum holds potential for glacial inception. Quaternary Science Reviews 26, 3025-3029.

Müller, U.C., Pross, J., Bibus, E., 2003. Vegetation response to rapid climate change in Central Europe during the last 135,000 years: Evidence from a new long pollen record. Quaternary Research 59, 235-245.

Müller, U.C., Pross, J., Tzedakis, P.C., Gamble, C., Kotthoff, U., Schmiedl, G., Wulf, S., Christanis, K., 2011. The role of climate in the spread of modern humans into Europe. Quaternary Science Reviews 30, 273-279.

National Research Council, 2002. Abrupt climate change: Inevitable surprises. National Academy Press, Washington, D.C.

NGRIP members, 2004. High-resolution record of Northern Hemisphere climate extending into the last interglacial period. Nature 431, 147-151.

NEEM community members, 2013. Eemian interglacial reconstructed from a Greenland folded ice core. Nature 493, 489-494.

Neugebauer, I., Brauer, A., Schwab, M. J., Waldmann, N.D., Enzel, Y., Kitagawa, H., Torfstein, A., Frank, U., Dulski, P., Agnon, A., Ariztegui, D., Ben-Avraham, Z., Golstein, S. L., Stein, M., DSDDP Scientific Party, 2014. Lithology of the long sediment record recovered by the ICDP Dead Sea Deep Drilling Project (DSDDP). Quaternary Science Reviews 102, 149-165.

Osborne, A.H., Marino, G., Vance, D., Rohling, E. J., 2010. Eastern Mediterranean surface water Nd during Eemian sapropel S5: Monitoring northerly (mid-latitude) versus southerly (sub-tropical) freshwater contributions. Quaternary Science Reviews 29, 2473-2483.

Panagiotopoulos, K., Aufgebauer, A., Schäbitz, F., Wagner, B., 2013. Vegetation and climate history of the Lake Prespa region since the Lateglacial. Quaternary International 293, 157-169.

Peyron, O., Goring, S., Dormoy, I., Kotthoff, U., Pross, J., de Beaulieu, J.-L., Drescher-Schneider, R., Vanniére, B., Magny, M., 2011. Holocene seasonality changes in the central Mediterranean region reconstructed from the pollen sequences of Lake Accesa (Italy) and Tenaghi Philippon (Greece). Holocene 21, 131-146.

Pillans, B., Gibbard, P., 2012. The Quaternary period. In: Gradstein, F., Ogg, J.G., Schmitz, M., Ogg, G. (Eds.), The Geologic time scale 2012. Elsevier, Amsterdam, pp.979-1010.

Piontek, F., Müller, C., Pugh, T. A. M., Clark, D. B., Deryng, D., Elliott, J., González, F., Flörke, M., Folberth, C., Franssen, W., Frieler, K., Friend, A.D., Gosling, S. N., Hemming, D., Khabarov, N., Kim, H., Lomas, M.R., Masaki, Y., Mengel, M., Morse, A., Neumann, K., Nishina, K., Ostberg, S., Pavlick, R., Ruane, A.C., Schewe, J., Schmid, E., Stacke, T., Tang, Q., Tessler, Z.D., Tompkins, A.M., Warszawski, L., Wisser, D., Schellnhuber, H.J., 2014. Multisectoral climate impact hotspots in a warming world. Proceedings of the National Academy of Science of the USA 111, 3233-3238.

Pons, A., Guiot, J., de Beaulieu, J.L., Reille, M., 1992. Recent contributions to the climatology of the last glacialinterglacial cycle based on French pollen sequences. Quaternary Science Reviews 11, 439-448.

Pons, A., Reille, M., 1988. The Holocene and Upper Pleistocene pollen record from Padul (Granada, Spain): A new study. Palaeogeography, Palaeoclimatology, Palaeoecology 66, 243-263.

Pross, J., Kotthoff, U., Müller, U.C., Peyron, O., Dormoy, I., Schmiedl, G., Kalaitzidis, S., Smith, A. M., 2009. Massive perturbation in terrestrial ecosystems of the Eastern Mediterranean region associated with the $8.2 \mathrm{kyr}$ BP climatic event. Geology 37, 887-890.

Pross, J., Tzedakis, P.C., Christanis, K., Schmiedl, G., Hooghiemstra, H., Müller, U.C., Kotthoff, U., Milner, A., 2007. Tenaghi Philippon re-visited: Drilling a continuous lower-latitude terrestrial climate archive of the last 250,000 years. Scientific Drilling 5, 30-32.

Pyle, D. M., Ricketts, G.D., Margari, V., van Andel, T.H., Sinitsyn, A. A., Praslov, N.D., Lisitsyn, S., 2006. Wide dispersal and deposition of distal tephra during the Pleistocene 'Campanian Ignimbrite/Y5' eruption, Italy. Quaternary Science Reviews 25, 2713-2728.

Quézel, P., 1968. Signification phytosociologiques des Gesnériacées grèques. Collectanea Botanica 8, 947-973.

Roether, W., Manca, B.B., Klein, B., Bregant, D., Georgopoulos, D., Beitzel, V., Kovacevic, V., Luchetta, A., 1996. Recent changes in eastern Mediterranean deep waters. Science 271, 333-335.

Rohling, E.J., Foster, G.L., Grant, K.M., Marino, G., Roberts, A.P., Tamisiea, M.E., Williams, F., 2014. Sea- 
level and deep-sea-temperature variability over the past 5.3 million years. Nature 508, 477-482.

Rohling, E.J., Marino, G., Grant, K.M., 2015. Mediterranean climate and oceanography, and the periodic development of anoxic events (sapropels). Earth-Science Reviews 143, 62-97.

Rohling, E.J., Mayewski, P.A., Abu-Zied, R.H., Casford, J.S. L., Hayes, A., 2002. Holocene atmosphere-ocean interactions: records from Greenland and the Aegean Sea. Climate Dynamics 18, 587-593.

Saaroni, H., Bitan, A., Alpert, P., Ziv, B., 1996. Continental polar outbreaks into the Levant and Eastern Mediterranean. International Journal of Climatology 16, 11751191.

Sagnotti, L., Scardia, G., Giaccio, B., Liddicoat, J.C., Nomade, S., Renne, P.R., Sprain, C.J., 2014. Extremely rapid directional change during Matuyama-Brunhes geomagnetic polarity reversal. Geophysical Journal International 199, 1110-1124.

Schmiedl, G., Kuhnt, T., Ehrmann, W., Emeis, K.-C., Hamann, Y., Dulski, P., Pross, J., 2010. Climatic forcing of eastern Mediterranean deep-water formation and benthic ecosystems during the past 22,000 years. Quaternary Science Reviews 29, 3006-3020.

Severinghaus, J.P., Sowers, T., Brook, E.J., Alley, R.B., Bender, M.L., 1998. Timing of abrupt climate change at the end of the Younger Dryas interval from thermally fractionated gases in polar ice. Nature 391, 141-146.

Shotyk, W., Weiss, D., Appleby, P.G., Cheburkin, A.K., Frei, R., Gloor, M., Kramers, J.D., Reese, S., van der Knaap, W. O., 1998. History of atmospheric lead deposition since $12,370{ }^{14} \mathrm{C}$ yr BP recorded in a peat bog profile, Jura Mountains, Switzerland. Science 281, 1635-1640.

Sklavounos, S., 1981. The Paranesti granite; mineralogy petrography. Dissertation, Aristotle University of Thessaloniki [in Greek].

Smit, A., Wijmstra, T. A., 1970. Application of transmission electron microscope analysis to the reconstruction of former vegetation. Acta Botanica Neerlandica 19, 867876.

Soldatos, T., Christofides, G., 1986. Rb-Sr geochronology and origin of the Elatia Pluton, central Rhodope, North Greece. Geologica Balcanica 16, 15-23.

Sulpizio, R., Zanchetta, G., D’Orazio, M., Vogel, H., Wagner, B., 2010. Tephrostratigraphy and tephrochronology of Lakes Ohrid and Prespa, Balkans. Biogeosciences 7, 3273-3288.

Stockhecke, M., Kwiecien, O., Vigliotti, L., Anselmetti, F.S., Beer, J., Çağatay, M.N., Channell, J.E.T., Kipfer, R., Lachner, J., Litt, T., Pickarski, N., Sturm, M., 2014. Chronostratigraphy of the 600,000 year old continental record of Lake Van (Turkey). Quaternary Science Reviews 104, 8-17.

St. Seymour, K., Christanis, K., Bouzinos, A., Papazisimou, S., Papatheodorou, G., Moran, E., Dénès, G., 2004. Tephrostratigraphy and tephrochronology in the Philippi peat basin, Macedonia, Northern Hellas (Greece). Quaternary International 121, 53-65.
Teichmüller, M., 1968. Zur Petrographie und Diagenese eines fast $200 \mathrm{~m}$ mächtigen Torfprofils (mit Übergängen zur Weichbraunkohle?) im Quartär von Philippi (Mazedonien). Geologische Mitteilungen 8, 65-110.

Tourloukis, V., Karkanas, P., 2012. The Middle Pleistocene archaeological record of Greece and the role of the Aegean in hominin disperials: new data and interpretations. Quaternary Science Reviews 43, 1-15.

Tsiripidis, I., Athanasiadis, N. A., 2003. Contribution to the knowledge of the vascular flora of northeast Greece: floristic composition of the beech (Fagus sylvatica L.) forests in Greek Rodopi. Willdenowia 33, 273-297.

Turner, J., Greig, J. R. A., 1975. Some Holocene pollen diagrams from Greece. Review of Palaeobotany and Palynology 20, 171-204.

Turney, C.S.M., 1998. Extraction of rhyolitic component of Vedde microtephra from minerogenic lake sediments. Journal of Paleolimnology 19, 199-206.

Tzedakis, P.C., 1993. Long-term tree populations in Northwest Greece through multiple Quaternary climatic cycles. Nature 364, 437-440.

Tzedakis, P.C., 2007. Seven ambiguities in the Mediterranean palaeoenvironmental narrative. Quaternary Science Reviews 26, 2042-2066.

Tzedakis, P.C., Hooghiemstra, H., Pälike H., 2006. The last 1.35 million years at Tenaghi Philippon: revised chronostratigraphy and long-term vegetation trends. Quaternary Science Reviews 25, 3416-3430.

Van der Hammen, T., Wijmstra, T. A., Van der Molen, W. H., 1965. Palynological study of a very thick peat section in Greece, and the Würm-glacial vegetation in the Mediterranean region. Geologie en Mijnbouw 44, 37-39.

Van der Wiel, A.M., Wijmstra, T.A., 1987a. Palynology of the lower part (78-120 m) of the core Tenaghi Philippon II, Middle Pleistocene of Macedonia, Greece. Review of Palaeobotany and Palynology 52, 73-88.

Van der Wiel, A.M., Wijmstra, T.A., 1987b. Palynology of the 112.8-197.8 $\mathrm{m}$ interval of the core Tenaghi Philippon III, Middle Pleistocene of Macedonia, Greece. Review of Palaeobotany and Palynology 52, 89-117.

Wagner, B., Wilke, T., Krastel, S., Zanchettta, G., Sulpizio, R., Reicherter, K., Leng, M. J., Grazhdani, A., Trajanovski, S., Francke, A., Lindhorst, K., Levkov, Z., Cvetkoska, A., Reed, J.M., Zhang, X., Lacey, J.H., Wonik, T., Baumgarten, H., Vogel, H., 2014. The SCOPSCO drilling project recovers more than 1.2 million years of history from Lake Ohrid. Scientific Drilling 17, 19-29.

Wijmstra, T.A., 1969. Palynology of the first $30 \mathrm{~m}$ of a $120 \mathrm{~m}$ deep section in northern Greece. Acta Botanica Neerlandica 18, 511-527.

Wijmstra, T. A., Groenhart, M.C., 1983. Record of 700,000 years vegetational history in Eastern Macedonia (Greece). Revista de la Academia Colombiana de Ciencias Exactas, Fisicas y Naturales 15, 87-98.

Wijmstra, T.A., Smit, A., 1976. Palynology of the middle part (30-78 meters) of a $120 \mathrm{~m}$ deep section in northern Greece (Macedonia). Acta Botanica Neerlandica 25, 297-312. 
Wijmstra, T.A., Young, R., 1992. Vegetational and climatic transitions between interglacial and glacial periods during the last 1 million years in northern Greece. In: Kukla, G. J., Went, E. (Eds.), Start of a Glacial. NATO ASI Series 13, 97-112.

Wijmstra, T. A., Young, R., Witte, H. J.L., 1990. An evaluation of the climatic conditions during the Late Quaternary in northern Greece by means of multivariate analysis of palynological data and comparison with recent phytosociological and climatic data. Geologie en Mijnbouw 69, 243-251.

Wu, P., Haines, K., Pinardi, N., 2000. Towards an understanding of deep water renewal in the eastern Mediterranean. Journal of Physical Oceanography 30, 443-458.

Wulf, S., Kraml, M., Kuhn, T., Schwarz, M., Inthorn, M., Keller, J., Kuscu, I., Halbach, P., 2002. Marine tephra from the Cape Riva eruption (22 ka) of Santorini in the Sea of Marmara. Marine Geology 183, 131-141.

Xoplaki, E., González-Rouco, J.F., Luterbacher, J., Wanner, H., 2003. Mediterranean summer air temperature variability and its connection to the large-scale atmospheric circulation and SSTs. Climate Dynamics 20, 723-739.
Xoplaki, E., Maheras, P., Luterbacher, J., 2001. Variability of climate in meridional Balkans during the periods 1675-1715 and 1780-1830 and its impact on human life. Climatic Change 48, 581-615.

Zervakis, V., Georgopoulos, D., Drakopoulos, P.G., 2000. The role of the North Aegean in triggering the recent eastern Mediterranean climatic changes. Journal of Geophysical Research 105, 26103-26116.

Zhou, L. P., Shackleton, N. J., 1999. Misleading positions of geomagnetic reversal boundaries in Eurasian loess and implications for correlation between continental and marine sedimentary sequences. Earth and Planetary Science Letters 168, 117-130.

Ziegler, M., Tuenter, E., Lourens, L. J., 2010. The precession phase of the boreal summer monsoon as viewed from the eastern Mediterranean (ODP Site 968). Quaternary Science Reviews 29, 1481-1490.

Manuscript received: February 13, 2015; rev. version accepted: April 29, 2015. 